\title{
Deciphering the Role of Host Genetics in Susceptibility to Severe COVID-19
}

\author{
Madalina Elena Carter-Timofte 1,2, Sofie Eg Jørgensen ${ }^{1,2}$, Mette Ratzer Freytag ${ }^{1,2}$, \\ Michelle Mølgaard Thomsen 1,2, Nanna-Sophie Brinck Andersen ${ }^{1,2}$, Ali Al-Mousawi 1,2, \\ Alon Schneider Hait ${ }^{1,2}$ and Trine H. Mogensen ${ }^{1,2,3 *}$ \\ ${ }^{1}$ Department of Biomedicine, Aarhus University, Aarhus, Denmark, ${ }^{2}$ Department of Infectious Diseases, Aarhus University \\ Hospital (AUH), Aarhus, Denmark, ${ }^{3}$ Department of Clinical Medicine, Aarhus, Denmark
}

\section{OPEN ACCESS}

Edited by:

Anne Puel,

Institut National de la Santé et de la

Recherche Médicale (INSERM), France

Reviewed by:

Sergio Rosenzweig,

National Institutes of Health (NIH),

United States

Carlos Rodríguez Gallego, University Hospital of Gran Canaria Dr.

Negrin, Spain

*Correspondence:

Trine H. Mogensen trine.mogensen@biomed.au.dk

Specialty section:

This article was submitted to Primary Immunodeficiencies,

a section of the journa

Frontiers in Immunology

Received: 08 May 2020

Accepted: 16 June 2020

Published: 30 June 2020

Citation:

Carter-Timofte ME, Jørgensen SE,

Freytag MR, Thomsen MM, Brinck Andersen N-S, Al-Mousawi A, Hait AS and Mogensen TH (2020) Deciphering the Role of Host Genetics in Susceptibility to Severe COVID-19.

Front. Immunol. 11:1606. doi: 10.3389/fimmu.2020.01606
Coronavirus disease-19 (COVID-19) describes a set of symptoms that develop following infection by the severe acute respiratory syndrome coronavirus 2 (SARS-CoV-2). Whilst COVID-19 disease is most serious in patients with significant co-morbidities, the reason for healthy individuals succumbing to fulminant infection is largely unexplained. In this review, we discuss the most recent findings in terms of clinical features and the host immune response, and suggest candidate immune pathways that may be compromised in otherwise healthy individuals with fulminating COVID-19. On the basis of this early knowledge we reason a potential genetic effect on host immune response pathways leading to increased susceptibility to SARS-CoV-2 infection. Understanding these pathways may help not only in unraveling disease pathogenesis, but also in suggesting targets for therapy and prophylaxis. Importantly such insight should instruct efforts to identify those at increased risk in order to institute preventative measures, such as prophylactic medication and/or vaccination, when such opportunities arise in the later phases of the current pandemic or during future similar pandemics.

Keywords: SARS-coronavirus 2, host immune defenses, immunopathology, innate immunity, primary immunodeficiency, whole exome sequencing

\section{INTRODUCTION}

In late December 2019, several cases of acute respiratory distress syndrome (ARDS) were reported across several provinces in China, and by March 2020, the World Health Organization (WHO) declared the current outbreak a global pandemic $(1,2)$. Six zoonotic coronaviruses are known to have the capability to cause respiratory disease in humans. The human coronaviruses (HCoV) 229E, NL63, OC43, and HKU1 are identified as weakly pathogenic, causing mild upper respiratory disease (3). However, during the last two decades, public health has been threatened by two highly pathogenic coronaviruses, including severe acute respiratory syndrome coronavirus (SARS-CoV) in 2002, and Middle-East respiratory coronavirus, (MERS-CoV) in 2012 (4). The 2019/20 outbreak was rapidly identified to be caused by a new member of the coronavirus family, namely SARS-CoV-2. This virus spreads by human-to-human transmission and early observational data has suggested a reproductive number of 2.2 days. Together with a mean incubation time of 5.2 days, SARS-CoV-2 has the ability to spread widely among humans (5). As of April 2020, $\sim 8.9$ million cases of coronavirus diseases (COVID-19) and 465,740 deaths have been reported globally according to the WHO. Whilst the majority of deaths have been of elderly individuals or patients with underlying health conditions, 
a small number of young and healthy people have also succumbed to fulminant infection. In these rare cases, host genetics may provide some explanation for failure to control SARS-CoV2 infection.

Primary immunodeficiencies (PIDs) are a group of genetically determined diseases predisposing individuals to severe infection, immune dysregulation, autoimmunity and malignancy $(6,7)$. There is increasing evidence that the extreme variability in the clinical outcome of infections can often be influenced by the germ line genetics of the human host (8). Such monogenic inborn errors of immunity predispose to a narrow or broad range of viral infections $(6,9,10)$. Examples include herpes simplex virus encephalitis and defects in the TLR3 pathway and RNA metabolism $(9,11,12)$, varicella-zoster virus and defective innate RNA POL III signaling (13-15), severe influenza and defects in IRF7 (16), IRF9 (17), TLR3 (18), GATA2 (19), and RIGI (20), rhinovirus infection and MDA5 (21), papillomaviruses and mutations in EVER1/2 (22), EBV lymphoproliferation and malignancy in the case of defects in SH2D1A (23), CD27, CD70 (24), XIAP (25), ITK (26), and MAGT1 (27), fatal CMV infection in NOS2 deficiency (28), and finally disseminated infection with measles vaccine strain virus in IFNAR and STAT2 deficiency $(29,30)$. In this review, we aim to discuss the most recent findings in terms of the innate and adaptive immune response to SARS-CoV-2, and draw on knowledge from the previous SARS-CoV and MERS-CoV outbreaks where relevant. This knowledge should enable us to speculate and to suggest essential antiviral pathways that may be defective in individuals at increased risk of severe COVID-19 and thus suggest genetic etiologies which may predispose otherwise healthy individuals without comorbidities to severe SARS-CoV2 infection.

\section{CLINICAL PRESENTATIONS OF COVID-19}

The severity of COVID-19 is extremely variable, with some individuals reporting almost no symptoms, whereas others become critically ill requiring intensive care and respiratory ventilation (31-33). The frequency of asymptomatic infections is yet to be determined and the differentiation between those and pre-symptomatic cases should be considered $(34,35)$. In the largest case report of 44,672 confirmed cases of COVID19 described by the Chinese CDC, an overall case fatality rate (CFR) of $2.3 \%$ was calculated (36). However, the mortality rates vary widely between different ages. No deaths were reported in children $<9$ years old, but the CFR increases to $14.8 \%$ in the $80+$ age group. In critical cases requiring ventilator support in the ICU, a CFR of 49-61\% was reported (36). Whilst severe disease outcomes have been reported in otherwise healthy individuals of any age, several risk factors are recognized that lead to a more critical disease course; these include old age, hypertension, diabetes, obesity, cardiovascular, pulmonary, and cerebrovascular disease (37).

COVID-19 initially presents with non-specific signs and symptoms of upper airway viral infection characterized by fever, fatigue, cough, and dyspnoea, as well as anorexia, myalgia, and productive sputum, which can develop to pneumonia $(32,38)$. Intriguingly, patients are increasingly reporting anosmia and dysgeusia, the loss of smell and taste, reflecting some neurological effect of SARS-CoV-2 (39), which has subsequently been confirmed by several reports of central and peripheral nervous system manifestations, with meningitis, encephalitis, myelitis, and Guillain-Barre syndrome presenting as components of severe COVID-19 $(40,41)$. In this context, respiratory failure has been hypothesized to be partly neurogenic in origin and possibly resulting from viral invasion of cranial nerve I into brainstem respiratory centers (41). Gastrointestinal symptoms, particularly nausea, vomiting, and diarrhea, are commonly described (42). In the most critical cases, widespread lung inflammation can lead to acute respiratory distress syndrome (ARDS), which often necessitates mechanical ventilation or extracorporeal membrane oxygenation (ECMO) to prevent total respiratory failure (43). Recent studies have demonstrated an extensive tendency for coagulopathy, thrombosis, micro-thrombosis, and disseminated intravascular coagulation during severe COVID-19 (44, 45) which is reflected in elevated fibrin and D-dimer levels during disease (46). Furthermore, a significant fraction of deceased ICU patients have pulmonary thrombosis or deep vein thrombosis as revealed by autopsy results (47).

Several clinical and immunological studies have suggested that excessive inflammation and a cytokine storm play a key role in the immunopathology, responsible for much of the lung damage, morbidity and mortality in patients with severe COVID19 in ICUs (48-50). This concept opens up the possibility that medical treatments that dampen immune activation may represent an important strategy in treating this disease and decreasing the high mortality $(51,52)$. Finally, there is emerging evidence that some infants and children have presented with a clinical picture of auto-inflammation and vasculitis, diagnosed as atypical Kawasaki's disease (53), a rare disease entity causing systemic inflammation, fever, and vasculitis with a risk of developing aneurisms. This inflammatory condition associated with a previous SARS-CoV-2 infection has been named Pediatric Multisystem Inflammatory Syndrome temporally associated with SARS-CoV-2 (PIMS-TS) (54).

\section{SARS-CoV-2}

Coronaviruses are enveloped, positive-sense, single-stranded viruses that contain the largest genome amongst RNA viruses $(27-32 \mathrm{~kb})(55,56)$. SARS-CoV-2 belongs to the Betacoronavirus genera, based on its phylogenetic relationship with other Betacoronaviruses, such as SARS-CoV and MERS-CoV $(57,58)$. Whilst SARS-CoV-2 shares 79\% nucleotide sequence identity with SARS-CoV, Zhou et al. reported the SARS-CoV-2 sequence to be $96.2 \%$ identical to the sequence of the horseshoe bat coronavirus, RaTG13, suggesting that SARS-CoV-2 originates from this bat species (58). An intermediate animal host between horseshoe bats and humans, as well as the transmission route, has yet to be identified in the SARS-CoV-2 pandemic (59). However, the most prevalent hypothesis is that the virus acquired one or several mutations allowing it to cross species barriers and infect 
human cells some time in autumn 2019, a few months before the beginning of the current pandemic (60).

Like other coronaviruses, the major structural proteins of SARS-CoV-2 include the envelope (E), membrane (M) and spike (S) proteins (61). In the earlier SARS-CoV epidemic, the $S$ protein was shown to facilitate cellular entry by binding to the angiotensin-converting enzyme 2 (ACE2) receptor present on target cells (62). In addition, the cellular serine protease transmembrane protease serine 2 (TMPSS2) is needed for priming of the $S$ protein and subsequent fusion of SARS$\mathrm{CoV}$ with the host cell membrane $(63,64)$. Furthermore, overexpression of ACE2 enhances disease severity in mice upon SARS-CoV infection, indicating the importance of this receptor in facilitating viral entry (65). Several studies have shown that the S protein of SARS-CoV-2 also uses ACE2 and TMPRSS2 for cell entry, and that the SARS-CoV-2 S protein is able to bind to ACE2 with 10 - to 20 -fold higher affinity than the SARS-CoV $S$ protein (66-69). Furthermore, ACE2 is highly expressed by type II alveolar epithelial cells $(70,71)$ which correlates with the pulmonary symptoms of COVID-19 (32). However, ACE2 is also highly expressed by intestinal, heart, kidney and bladder cells $(71,72)$. This pattern of cellular ACE2 expression may explain some of the non-respiratory symptoms and complications that SARS-CoV-2 patients exhibit, such as diarrhea, kidney failure and cardiac injury $(32,73)$.

\section{INNATE IMMUNE RESPONSES TO SARS-CoV-2}

The innate immune response is the first line of defense against a wide range of pathogens, particularly viruses. Importantly, viral infection induces type I interferons (IFN) $(\operatorname{IFN} \alpha / \beta)$ and type III IFNs (IFN- $\lambda$ ), which activate hundreds of antiviral proteins as well as mediate priming the adaptive immune response (Figure 1). Coronaviruses, and their nucleic acid genome and replication intermediates in particular, are recognized primarily by two groups of pattern recognition receptors, namely the Toll-like receptors (TLRs) and the retinoic acid inducible

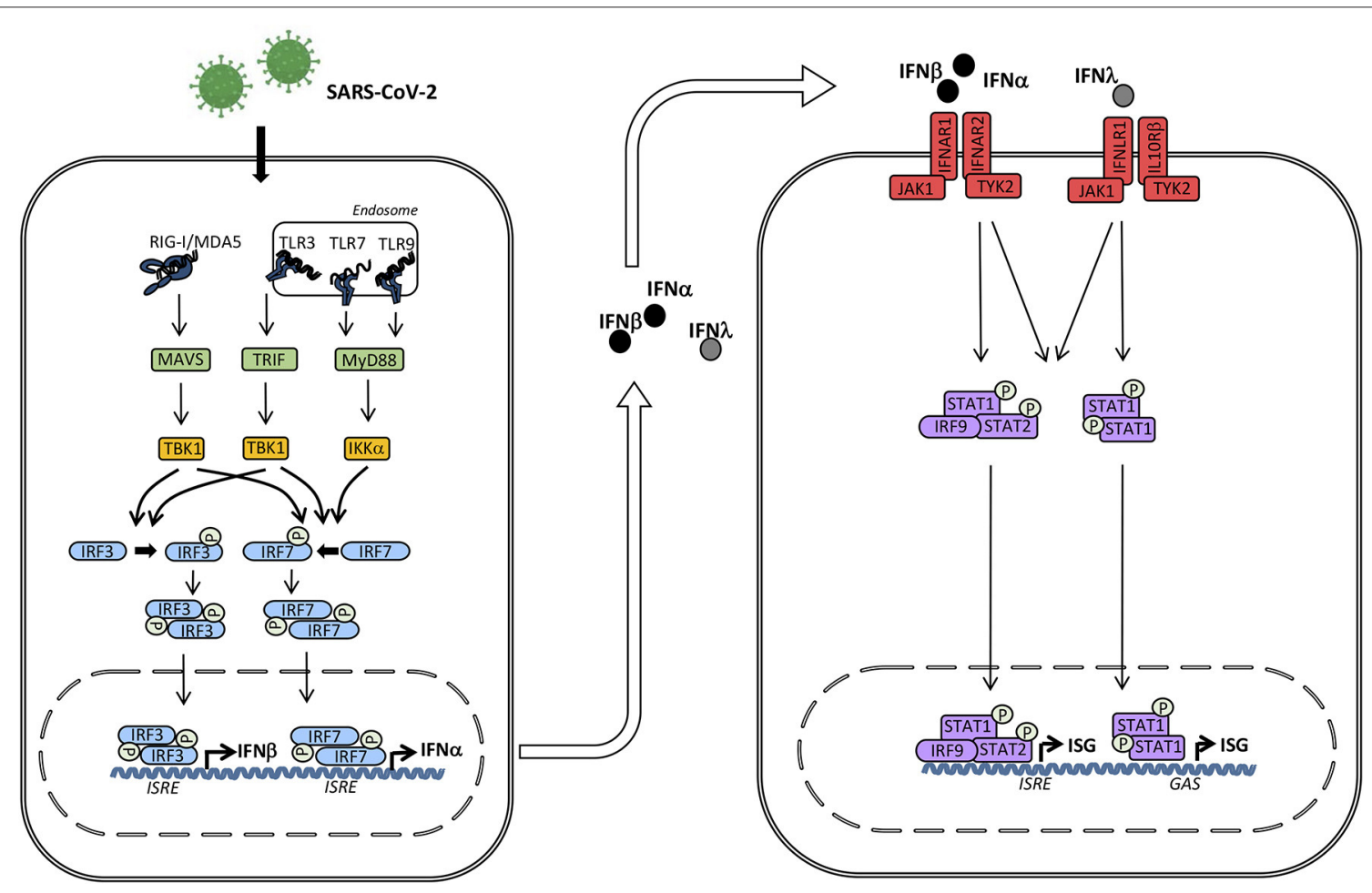

FIGURE 1 | Induction of interferons (IFN) and signaling by the type I and III IFN receptors. The presence of microbial or self nucleic acid in the cytosol or within the endosomal compartment activates pattern recognition receptors (PRR)s. RNA activates retinoic acid-inducible receptor (RIG)-I in the cytosol and Toll-like receptor (TLR) 3 and TLR7 in the endosomal compartment. These events trigger signaling pathways through the adaptor molecules mitochondrial antiviral signaling protein (MAVS), TIR-domain-containing adapter-inducing interferon- $\beta$ (TRIF), and Myeloid differentiation primary response (MyD)88 leading to phosphorylation and activation of the TANK binding kinase (TBK)1, which in turn phosphorylates the transcription factors IFN regulatory factor (IRF)3 and IRF7. Whereas IRF3 is constitutively present, IRF7 is only expressed at low levels but may be secondarily induced by Type I IFN. Phosphorylation of IRF3 and IRF7 leads to homodimerization, nuclear translocation, and expression of Type I IFNs (IFN $\alpha$ and IFN $\beta$ ) and type III IFNs (IFN $\lambda$ ) acting on neighboring cells with type I and III IFN receptors, respectively. Type I IFN binds to IFN $\alpha / \beta$ receptor composed of IRFNAR1 and IFNAR2, whereas type III IFN binds to the IFN $\lambda$ receptor composed of IFNLR1 and IL10R $\beta$. These events activate the downstream receptor-associated Janus-associated kinase (JAK)1 and tyrosine kinase (TYK)2 and subsequent tyrosine phosphorylation of STAT1 and STAT2. These activated transcription factors together with IRF9 form the heterotrimeric transcription factor IFN-stimulated gene factor (ISGF) 3 complex which binds to IFN-stimulated regulatory elements (ISRE) in DNA. In addition, STAT1 homodimers form the IFN- $\gamma$-activated factor (GAF) complex which binds to $\gamma$-activated (GAS) sequences. Altogether, these transcription factors induce a broad spectrum of IFN-stimulated genes (ISG)s that mediate the complex "antiviral state" of IFNs. 
gene I (RIG-I)-like receptors (RLRs). These receptors recognize several viral components, which induce downstream signaling and result in production of antiviral type I and III IFNs as well as proinflammatory cytokines through activation of the transcription factors interferon regulatory factor (IRF)3, IRF7 and nuclear factor(NF)-кB (74) (Figure 1).

The TLRs which have so far been implicated in the response to SARS-CoV, are TLR3, -4 and -7 (Figure 2). TLR3 recognizes double-stranded RNA (dsRNA), and the coronavirus-derived ligand is likely a double-stranded replication intermediate. The ligand for TLR4 remains obscure, as TLR4 usually recognizes lipopolysaccharide from gram negative bacteria. Finally, special GU-rich sequences in the SARS-CoV genome activate TLR7 (75). TLR3 and TLR4 activate the adaptor TIR-domain-containing adapter-inducing interferon- $\beta$ (TRIF), whereas myeloid differentiation primary response 88 (MyD88) is the adaptor used by all other TLRs (76) (Figure 2). Insights from mouse knock-out studies may provide some knowledge as to which signaling pathways are important in SARS-CoV2 recognition, and where we might expect to identify genetic variants, which predispose to more severe COVID-19 disease.

Several studies have demonstrated that infection of $T l r 3^{-/-}$,

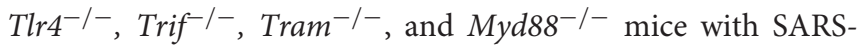
$\mathrm{CoV}$ causes increased viral replication, enhanced pathology in the lungs, and increased morbidity (77-79). The most severe phenotypes and mortality are generally seen in mice lacking the downstream adaptors TRIF and MyD88 (77, 78). Interestingly, following SARS-CoV infection of Trif ${ }^{-/-}$ mice, the aberrant proinflammatory cytokine and chemokine responses were similar to those seen in human patients with poor disease outcome during SARS-CoV infection (80) or MERS-CoV infection (81). This may suggest that the initial impaired control of viral replication could lead to exaggerated immune responses and enhanced immunopathology later during infection. However, MyD88 and IRAK4 seem to be largely redundant in antiviral immunity in humans, since previous

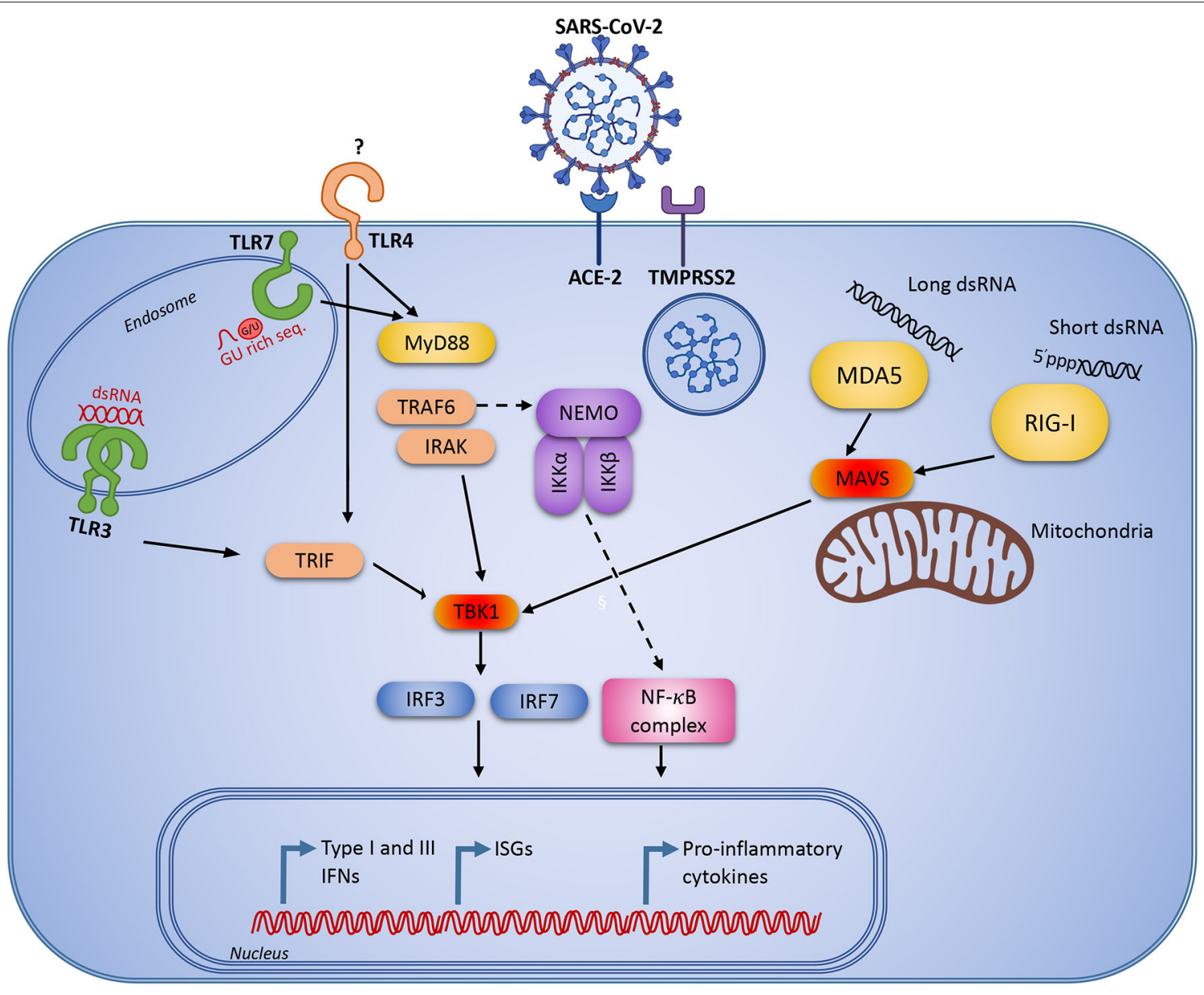

FIGURE 2 | Innate immune signaling pathways that are known to be activated during viral infection and replication. Severe acute respiratory syndrome coronavirus 2 (SARS-CoV-2) infects human cells through the angiotensin-converting enzyme 2 (ACE2 receptor) and the cellular serine protease TMPRSS2 for viral S protein priming Following cellular entry, the virus RNA genome may be recognized by pattern recognition receptors (PRR)s, including endosomal Toll-like receptor (TLR) 3 and TLR7 recognizing double-stranded and single-stranded RNA, respectively. In the cytosol the virus may be recognized by the retinoic acid inducible receptor (RIG)-I or the melanoma differentiation-associated protein (MDA)5. Following viral recognition by PRRs, this triggers signaling through IFN regulatory factor (IRF)3 and NF-kB to induce IFNs and pro-inflammatory cytokines. Similar responses may be activated by extracellular virus through TLR4. 
studies have failed to report increased susceptibility to severe viral infection in patients deficient in these molecules (82). This underlines the value of studying the spectrum of infections in patients with well-defined immunodeficiencies in natura, revealing important lessons on protective immunity in humans $(10,83)$.

Coronaviruses are, in addition to being recognition by TLRs, also recognized by RLRs. The RLRs are cytosolic RNA sensors, where RIG-I recognizes short dsRNA with 5' triphosphate, and melanoma differentiation-associated protein 5 (MDA5) recognizes long dsRNA. MDA5 is clearly protective in mice infected with the murine coronavirus mouse hepatitis virus (MHV) (84), whereas there are only limited reports indicating that the other RLRs are important in SARS-CoV infection. This is, however, not due to the virus failing to be recognized by the receptors, but rather because SARS-CoV, as well as other coronaviruses, employs several strategies to avoid recognition and immune activation. For example, deletion of the SARS-CoV nsp16 gene, an enzyme which catalyzes ribose 2'-O-methylation to generate caps on the coronavirus RNA (85), attenuates the pathogenicity of the virus $(86,87)$. However, in the absence of MDA5 or Interferon Induced Protein With Tetratricopeptide Repeats 1 (IFIT1), the SARS-CoV nsp16 deletion mutant reached similar levels of viral replication and virulence as wild type SARS$\operatorname{CoV}(86,87)$, indicating that MDA5 recognizes partly uncapped SARS-CoV RNA. The recognition of SARS-CoV by RIG-I has not yet been described, probably due to the fact that RIG-I has a preference for short dsRNA and also because the initial steps of capping impairs RIG-I recognition by removing the 5 'triphosphate (85).

Investigations into the role of lung inflammation during respiratory infection identified a potential role for excessive inflammasome activation. Mice in which the inflammasome pathway had been deleted by CASP1/11 knock-out displayed less mortality upon influenza infection compared to wild-type mice (88). Furthermore, inflammation was shown to be driven by excessive neutrophil activation. Given that neutrophilia is a paraclinical indication of COVID-19 disease severity, we might predict that inhibiting this response may improve outcomes in SARS-CoV-2 infection. These studies are supported by other data demonstrating that the NACHT, LRR and PYD domainscontaining protein 3 (NLRP3) inflammasome activation by the SARS-CoV viral proteins, E, ORF-8b and viroporin $3 \mathrm{a}$ (89-91). Importantly, coronaviruses can induce pyroptosis via NLRP3 in a process involving insertion of Gasdermin D in the cellular membrane (92). Furthermore, several publications have implicated neutrophils and neutrophil extracellular traps (NET) in organ damage, pulmonary pathology, micro-thrombosis, and mortality in COVID-19 $(93,94)$. NETs consist of extracellular webs of chromatin, microbicidal proteins and oxidant enzymes that are released by neutrophils to contain microbial infections but also have the potential to propagate inflammation and immunopathology (94).

IFNs are the most prominent antiviral effectors of the innate immune system, and SARS-CoV infection is highly susceptible to this potent antiviral substance, as shown by the efficient inhibition of viral replication upon administration of exogenous
IFN both in vitro and in vivo (95-100). However, only very limited amounts of IFNs are actually produced during SARS$\mathrm{CoV}$ and MERS-CoV infections (101), and the response seems to be delayed relative to the production of proinflammatory cytokines (102). However, it is worth noting that these antiviral responses are most likely cell-type specific. A recent study demonstrated that SARS-CoV-2 also induces significantly less alveolar cell IFN and ISG expression compared to influenza A and respiratory syncytial virus in vitro (103). In support of these data, a comparative study reported more efficient viral replication and a reduced type I IFN response in SARSCoV-2 infection of ex-vivo human lung cultures compared to SARS-CoV (104). To achieve this very low IFN production, the coronaviruses are known to employ numerous strategies to counteract the innate immune signaling pathways of the host, which have been reviewed elsewhere (101, 105-107). However, the exact mechanisms by which SARS-CoV-2 appears to more efficiently prevent IFN production, and if this is partly responsible for increased pathogenicity in the current outbreak, remains elusive. Collectively, future identification of the molecules and signaling pathways targeted by SARS-CoV2 will provide essential information on key antiviral modalities, which may also be those defective in patients with genetic predisposition to severe disseminated COVID-19.

\section{ADAPTIVE IMMUNE RESPONSES TO SARS-CoV-2}

The cell-mediated immune response plays a critical role in antiviral immunity, and developing early and robust $\mathrm{CD}^{+}$and in particular, $\mathrm{CD} 4^{+} \mathrm{T}$ cell responses correlates well with positive outcomes during SARS-CoV infection (108, 109). Clinical investigations of severe COVID-19 patients consistently report neutrophilia and lymphopenia, with significantly depressed $\mathrm{CD}^{+}{ }^{+} \mathrm{T}$ cell counts and decreased IFN- $\gamma$ expression, as well as reduced numbers of regulatory and memory $\mathrm{T}$ cells $(37,110$, 111). In addition, increased levels of plasma pro-inflammatory cytokines such as Interleukin (IL)-1 $\beta$, IL-6, IL-8, and tumor necrosis factor- $\alpha$ (TNF-a) are observed in severe COVID-19 patients, indicative of a cytokine storm and subsequent ARDS development $(32,73)$. In support of these data, a study of 522 hospitalized COVID-19 patients reported a negative correlation between T cell numbers and serum IL-6, IL-10 and TNF- $\alpha$ levels (112). Furthermore, COVID-19 patients displayed increased expression of the $\mathrm{T}$ cell exhaustion markers, programmed cell death protein-1 (PD-1) and Tim-3, compared to healthy controls, suggesting that $\mathrm{T}$ cell survival and activation may play a role in protecting the host from severe SARS-CoV-2 development (112, 113). Studies investigating $T$ cell phenotypes in asymptomatic or convalescent COVID-19 patients have been more limited. However, a recent study (114) identified circulating SARS-CoV2 -specific $\mathrm{CD}^{+}$and $\mathrm{CD}^{+} \mathrm{T}$ cells in $\sim 70 \%$ and $100 \%$ of recovered COVID-19 patients, respectively. Importantly, this study reported the presence of SARS-CoV-2-reactive CD4 ${ }^{+} \mathrm{T}$ cells in healthy donors recruited in 2015-2018 (114). These data suggest that there is a cross-reactive coronavirus T cell memory 
response, but whether such pre-existing immunity influences clinical outcomes remains to be determined.

Cytotoxic $T$ cells are important for clearing respiratory viruses and providing long-term protection; however, the magnitude of this response must be well-controlled to prevent pathological consequences $(74,115)$. Histological examination of a patient who died from severe SARS-CoV-2 infection identified that whilst the overall peripheral $\mathrm{CD}^{+}$and $\mathrm{CD}^{+}{ }^{+} \mathrm{T}$ cell counts were significantly reduced, alveolar $\mathrm{CD}^{+} \mathrm{T}$ cells harbored high concentrations of cytotoxic granules, which may have contributed to severe tissue injury (116). Moreover, lung biopsy revealed desquamation of pneumocytes, pulmonary oedema, and hyaline membrane formation, indicative of early-stage ARDS development (116). On the other hand, a robust $\mathrm{CD} 8^{+} \mathrm{T}$ cell response is known to be important in SARS-CoV infection, and mild cases of COVID-19 have increased clonal expansion of $\mathrm{CD}^{+} \mathrm{T}$ cells, compared to severe cases (117). The pathological features of COVID-19 resemble those of SARS and MERS, both of which are thought to be largely caused by immune dysregulation rather than direct pathology induced by high viral load $(111,118)$, with a similar picture emerging for SARS-CoV-2.

A considerable number of studies have demonstrated that infection with SARS-CoV-2 initiates an antibody response. On average, seroconversion is observed between 10 and 14 days post infection, a timeline similar to that observed for the previous SARS-CoV epidemic (58, 119-123). Serological investigations of 262 hospitalized COVID-19 patients across the Chongqing region, China, reported simultaneous or sequential seroconversion (IgM and $\operatorname{IgG}$ ) against recombinant antigens containing the nucleoprotein and a peptide from the spike protein of SARS-CoV-2 (124). Interestingly, IgG titers were higher in patients with severe COVID-19, compared to the nonsevere group (124). A number of studies have also reported earlier or increased antibody titers in critical vs. non-critical COVID-19 patients, possibly reflecting more severe and invasive infection and thus making it difficult to determine the specific nature of the association $(124,125)$ whereas others report no correlation between disease severity and serum antibody levels (126). Such discrepancies between findings may be explained not only by the relatively small number of individuals investigated per study, but also due to the fact that different assays are used in the different studies, likely causing significant sensitivity and specificity challenges (123). Importantly, however, SARS-CoV2 isolated from critically ill patients can be neutralized by sera from several patients, a finding that gives weight to the rapid development of therapeutic neutralizing antibodies (NAbs) as a potential means to control the current pandemic (58).

The possibility of re-infection with SARS-CoV-2 is a key area of investigation. Individuals who recovered from SARS-CoV or MERS-CoV infection displayed high tires of antibodies which waned after 2-3 years $(127,128)$. However, a small study of only three SARS-recovered individuals identified SARS-specific memory $\mathrm{T}$ cells 11 years after infection (129). Finally, the efficacy and longevity of immunity to SARS-CoV-2 is highly dependent upon the rate by which the virus alters its composition, i.e., the mutation rate. So far, studies suggest a relatively low virus mutation rate with mutations randomly spread throughout the viral genome, suggesting absence of positive selection toward increased virulence (60). Moreover, previous studies suggest that a virus crossing the species barrier is more likely to lose virulence over time than the opposite (130).

\section{HUMAN INBORN ERRORS OF IMMUNITY PREDISPOSING TO CORONAVIRUS INFECTION}

Several predisposing factors are known to increase the risk of progression to severe COVID-19 (37). However, there is currently no explanation as to why younger individuals with no co-morbidities in rare cases have developed life-threatening COVID-19. Human inborn errors of immunity can alter the course of various viral infections (131), but in the case of disease progression in SARS-CoV-2 infection, little is known regarding the influence of the host genetic makeup. However, any genetic variant that results in a dysregulated or exaggerated immune response may contribute to lung immunopathology leading to life-threatening clinical manifestations.

It has been proposed that deficient type I IFN production may undermine the innate immune response during early SARS$\mathrm{CoV}$ infection, resulting in a more severe disease course (80, 132, 133). Population studies have identified single nucleotide polymorphisms (SNPs) in the IFN-inducible genes OAS1 and $M X 1$, associated with susceptibility to SARS-CoV infection and disease progression $(134,135)$. Moreover, exogenous administration of type I IFN has been shown to inhibit SARSCoV replication both in vivo $(96,99)$ and in vitro $(95,97,100)$. Together, these data highlight the importance of an intact type I IFN pathway in the innate response to SARS-CoV, and it can be reasoned that any genetic mutations that impair this response may somehow predispose to COVID-19 disease progression. Consequently, it is worth considering that clinical outcome may be influenced by mutations of the PRRs and immune signaling pathways involved in recognition of SARS-CoV-2, including RIG-I, MDA5, and TLR3 and downstream IRF3 and IRF7, as well as molecules involved in effector function of type I and III IFN, such as IFNAR1/2 or the janus kinase (JAK) - signal transducer and activator of transcription (STAT) signaling pathways.

Emerging evidence suggests that activation of the complement system contributes to the pathogenesis of SARS-CoV-2 lung pathology $(136,137)$. Inhibition of the terminal complement pathway by targeting complement protein 5 (C5) has been proposed as an effective therapeutic intervention in CoVmediated disease (138). Mannose-binding lectin (MBL) is a pattern recognition molecule, which binds to specific carbohydrate structures on the microbial surface, thereby activating complement terminal pathways (139). MBL serum immunodeficiency has been suggested to play a role, although controversial, in increased susceptibility to a wide range of viral and bacterial infections, mainly in children (140-142). A single study has identified that individuals carrying a low MBL-producing haplotype YB have an increased risk of acquiring SARS-CoV (143). Collectively, the precise role of the 
complement system as either having a detrimental or protective role in COVID-19 pathogenesis needs further study.

Within adaptive immunity, the impact of PIDs associated with antibody deficiencies and combined immunodeficiencies on SARS-CoV-2 outcomes are not fully clarified. However, some important information may be retrieved from a description of severe lung pathology and COVID-19 disease course in patients with common variable immunodeficiency (CVID) compared to patients with pure agammaglobulinemia (144). Although the results were based on few patients, it was noted that patients with agammaglobulinemia experienced relatively mild disease. However, patients with similarly low immunoglobulin levels but immune dysregulation as part of CVID experienced more severe disease, suggesting a role of immune dysregulation and abnormal B immune cell phenotype and potentially excessive IL-6 production in COVID-19 pathogenesis, although T cell deficiency may also be involved (144). Collectively, results of studies into COVID-19 disease presentation and progression in patients with known PIDs are eagerly awaited. Such data may facilitate understanding of what constitutes an inadequate immune response toward SARS-CoV-2 and from this knowledge determine the molecular and cellular correlates of protective immune responses and immunity in COVID-19.

As to the role of $\mathrm{T}$ cells in protection from severe COVID19 , it would be expected that $\mathrm{T}$ cell lymphopenia from any source might represent an increased risk of severe viral infection. However, not much evidence suggests that patients with primary $\mathrm{T}$ cell defects nor HIV infection are at a significantly elevated risk. When large cohort studies of SARS-infected and MERS$\mathrm{CoV}$-infected patients from previous epidemics were reviewed, HIV infection was not identified as an independent risk factor for infection by these coronaviruses $(145,146)$. However, evidence for the role of $\mathrm{T}$ cell defects on prevalence and severity of COVID-19 is scarce, and it is therefore too early to draw any conclusions (147).

Based on insight into immunopathogenesis and pathology during COVID-19, potential susceptibility genes may be involved in mechanisms of immune dysregulation, auto-inflammation or autoimmunity, thus involving the gain-of-function or loss of inhibition of various genes and pathways in cytokine and TLR signaling cascades, especially those affecting IL-1 and IL6 synthesis and production (48-50). Likewise, genetic variants in endothelial cell biology and regulation may be anticipated to aggravate coagulopathy and thrombotic events. Specific evidence on such associations remains to be reported but should be part of searches in large unbiased whole exome sequencing approaches, such as the worldwide consortium (148) (covidhge.com).

Genetic variants in the major histocompatibility complex antigen loci (HLA) are well-known to influence host susceptibility to infectious disease (149). So far, only a limited number of studies have looked for an association between HLA haplotypes and genetic susceptibility or resistance to SARS coronavirus infection. However, an impact of HLA haplotypes may identify some of the unexplained differences in disease severity and mortality observed across different countries and different population ethnicities (150-154). Allele typing of 37 probable SARS patients in Taiwan identified an association between HLA-B*4601 and SARS-CoV infection (155); however, this was not confirmed in a study of 90 serologically confirmed SARS-CoV patients in Hong Kong $(156,157)$. The latter study instead identified an association between the HLA-B*0703 and HLA-DRB1*0301 genotypes and the development of SARS (157). In terms of the current pandemic, we might predict that genetic variations in the HLA molecules resulting in decreased binding specificities for SARS-CoV-2 peptides may confer a more severe COVID-19 disease course (158). Zhao et al. (159) investigated the relationship between $\mathrm{ABO}$ blood group and COVID-19 susceptibility in 2,173 Chinese patients. Interestingly, being of blood group A represented a higher risk for developing COVID-19 disease, whilst having blood group O was associated with a lower infection risk. A similar risk pattern for $A B O$ blood groups has also been reported for the 2003 SARS-CoV outbreak (160); however, the exact mechanism of how blood group antigens might affect susceptibility remains to be clarified.

Genetic studies have identified polymorphisms in the IL28B gene which have been linked to hepatitis $\mathrm{C}$ virus (HCV) clearance (161). The product of this gene is type III IFN (IFN- $\lambda$ ). Given that genetic variants in IFN- $\lambda$ appear to play an important role in the natural course of disease and severity during infection with $\mathrm{HCV}$, it will be interesting to investigate if polymorphisms in the $I L 28 B$ gene could also predispose to severe SARS-CoV2 infection. Perhaps the most compelling reason to believe that genetic differences may account for the vast diversity in COVID19 symptoms is a recent preprint study by British researchers who, using a mobile symptom tracker, recorded data from over 2.7 million app users. Analysis of same sex adult twins $(n=$ $2,000^{+}$) showed that genetic factors accounted for $50 \%$ of the difference in COVID-19 symptoms (162). Although the results from the latter studies will need to be verified, these data highlight how genetic differences may explain the great variability in SARSCoV-2 infection outcome.

As we start to gain further insight into the pathogenesis of severe COVID-19 and appreciate the major role played by inflammation and immunopathology, this raises the question as to whether there might be an increased risk of developing severe disease in certain individuals, and whether genes predisposing to those conditions should be investigated in a genetic approach. Such genes include NLRP1, NLRP3, CASP1, MEFV, and many others, which all encode proteins involved in inflammasome activation (163). Focus should also be on known genetic causes of hemophagocytic lymphohistiocytosis (HLH), including defects in the genes PRF1, UNC13D, STX11, STXBP2, LYST, RAB27A (164) either in the well-recognized homozygous forms, or possibly in heterozygous forms that may still predispose to HLH in the presence of a trigger, such as SARS-CoV-2 (165). However, the precise pathogenesis of macrophage activation syndrome and Kawasaki-like disease/PIMS in COVID-19 is not fully understood and may involve autoinflammation, autoimmunity, and/or immunopathology induced directly by the virus or as a secondary result of crossreactivity.

At the other end of the disease spectrum, there is the possibility that some individuals may avoid infection due to protective tissue types or gene mutations. The most prominent example to mention is the potential protective role of ACE2 
defects, rendering cells restistant to SARS-CoV-2 infection, in analogy to protection from HIV infection by Delta32 CCR5 homozygosity (166). Given the important role of host ACE2 in SARS-CoV-2 infection, we might speculate that ACE2 genetic polymorphisms may be present in certain individuals, which could be exploited by SARS-CoV-2 and lead to severe clinical disease. Equally, ACE2 polymorphisms may even offer some level of resistance. Indeed, one study has identified multiple rare genetic variants in $A C E 2$, which are predicted to modify virus-host interaction and alter susceptibility to SARS-CoV-2 (167). Another study has also reported rare, genetic variants in TMPRSS2 as possible disease modulators of SARS-CoV-2 infection in Italy (168). Although these findings necessitate functional validation, it gives weight to the hypothesis that rare, genetic mutations may explain COVID-19 disease severity.

\section{THERAPEUTIC DEVELOPMENTS AND TRIALS}

No therapeutics have yet been approved to treat diseases caused by SARS-CoV-2 or other coronaviruses $(169,170)$. By mid March 2020, WHO launched the global "Solidarity" clinical trial for COVID-19 treatments to assess the effectiveness of four potential therapeutic options, namely remdesivir, lopinavir/ritonavir with and without IFN- $\beta$, and chloroquine or hydroxychloroquine (171). Remdesivir, already early suggested to be the most promising compound $(172,173)$, is a pro-drug of an adenosine nucleotide analog, which upon incorporation in the growing RNA chain potently inhibits RNAdependent RNA polymerases inducing synthesis arrest (172, 174). Remdesivir has broad antiviral activity against several RNA viruses in vitro, including SARS-CoV-2 (174-177), and in vivo against SARS-CoV and MERS-CoV $(176,178,179)$. Whereas no significant improvement was observed in an initial trial of 237 patients receiving remdesivir (180), preliminary results from the larger Adaptive Covid-19 Treatment Trial (ACTT) showed that remdesivir significantly shortened the time to recovery in patients with lower airway involvement, and interestingly, another study found no difference between treatment with remdesivir for 5 days compared to 10 days (181, 182). However, importantly, remdesivir did not show major efficacy in patients with severe COVID-19 in the ICU (183), possibly because host responses may be major determinants at that stage, rather than viral replication. Promising results in controlling SARS-CoV-2 in vitro have also been demonstrated for the protease inhibitor lopinavir/ritonavir, licensed for HIV treatment $(184,185)$, as well as for chloroquine and hydroxychloroquine presently used in the treatment of malaria and autoimmune diseases $(175,186,187)$. However, a randomized trial including 199 COVID-19 patients showed no immediate in vivo benefits of lopinavir/ritonavir (188). Similarly, clinical trials on chloroquine and hydroxychloroquine have identified methodological limitations and conflicting results, even suggesting a negative effect of hydroxychloroquine (189195). In May 2020, a multinational analysis reported the use of hydroxychloroquine or chloroquine, with or without a macrolide, for treatment of COVID-19 comprising data from
671 hospitals in six continents (196). This study failed to show any beneficial effect of the two drugs; moreover, concerns were raised about whether these drugs caused higher inhospital mortality (197). Notably, the study was retracted shortly after publication, whereas the hydroxychloroquine studies currently continue after evaluation of the safety data by the WHO (198).

Agents which target the host are also potentially valuable treatment options. Interestingly, the agent camostat mesylate has been reported to block the cellular serine protease TMPRSS2, thereby inhibiting SARS-CoV-2 entry into host cells (67), and increases survival rates $\sim 60 \%$ in an in vivo SARS-CoV model (199). Camostat mesylate is widely used in Japan for chronic pancreatitis and postoperative reflux esophagitis (200, 201), and currently, a clinical trial in Denmark investigating the impact of this compound on COVID-19 is in its recruitment stage (202).

The effectiveness of agents blocking either IL-1 or IL6, i.e., the receptor-targeted monoclonal antibodies anakinra and tocilizumab, respectively, in the treatment of patients with severe COVID-19 in the ICU have received considerable interest due to the well-established role of these cytokines in immunopathology and association with poor clinical outcome $(32,63)$. Promising results have been reported for individuals or small groups of COVID-19 patients treated with tocilizumab $(203,204)$ and anakinra $(205,206)$, the latter potentially also beneficial in treating COVID-19 related HLH (207). The results of ongoing randomized, controlled clinical trials (50, 208 , 209) will ultimately determine whether such strategies to dampen immune responses will prove beneficial and safe. So far, no significantly increased tendency to severe COVID-19 was reported in patients receiving these medications (DMARDs) for the treatment of rheumatologic conditions (210). On a more hypothetical basis, the complement system has been suggested as a target for treatment (211). Finally, numerous ongoing studies are investigating additional novel therapeutic strategies (212) and candidate vaccines (213) against SARS-CoV-2. Despite the rapidly evolving number of publications on potential COVID19 therapeutics, thus far only a very limited number of welldesigned clinical trials are available. However, to evaluate the effectiveness and potential adverse effects of future treatments, the results of thorough large-scale, randomized, controlled trials are crucial. Notably, a number of fundamental immunological and virological questions need to be addressed before a vaccine candidate is available. These include aspects related to the mutation rate of the virus, the strength of immunity induced by SARS-CoV-2 and the relative contributions from humoral or cellular immunity, and not least the duration of a protective immune response.

\section{CONCLUDING REMARKS}

The current global COVID-19 pandemic is a major challenge for all involved in studies of the role of human genetics in the face of a novel infectious disease. Sequencing children and young or middle-aged individuals with severe COVID-19, who are otherwise healthy, will identify rare, deleterious mutations that lead to SARS-CoV-2 infection and severe clinical outcome. This will offer unique insights on the disease pathogenesis in natura, 
which will undoubtedly offer new therapeutic potentials (148). Coronaviruses appear at regular intervals, and understanding the molecular mechanisms of COVID-19 development is imperative not only to ending the current pandemic, but also for controlling future potential outbreaks.

\section{AUTHOR CONTRIBUTIONS}

TM conceived the idea, all authors contributed to the first version of the manuscript. MC-T and TM revised and

\section{REFERENCES}

1. Zhu N, Zhang D, Wang W, Li X, Yang B, Song J, et al. A novel coronavirus from patients with pneumonia in China, 2019. N Engl J Med. (2020) 382:72733. doi: 10.1056/NEJMoa2001017

2. Rothan HA, Byrareddy SN. The epidemiology and pathogenesis of coronavirus disease (COVID-19) outbreak. J Autoimmun. (2020) 109:102433. doi: 10.1016/j.jaut.2020.102433

3. Channappanavar R, Perlman S. Pathogenic human coronavirus infections: causes and consequences of cytokine storm and immunopathology. Semin Immunopathol. (2017) 39:529-39. doi: 10.1007/s00281-0170629-x

4. Fung TS, Liu DX. Human coronavirus: host-pathogen interaction. Annu Rev Microbiol. (2019) 73:529-57. doi: 10.1146/annurev-micro-020518-115759

5. Li Q, Guan X, Wu P, Wang X, Zhou L, Tong Y, et al. Early transmission dynamics in Wuhan, China, of novel coronavirus-infected pneumonia. $N$ Engl J Med. (2020) 382:1199-207.

6. Mogensen TH. IRF and STAT transcription factors - from basic biology to roles in infection, protective immunity, and primary immunodeficiencies. Front Immunol. (2018) 9:3047. doi: 10.3389/fimmu.2018.03047

7. Bousfiha A, Jeddane L, Picard C, Ailal F, Bobby Gaspar H, Al-Herz W, et al. The 2017. IUIS phenotypic classification for primary immunodeficiencies. $J$ Clin Immunol. (2018) 38:129-43. doi: 10.1007/s10875-017-0465-8

8. Casanova JL, Abel L. Human genetics of infectious diseases: unique insights into immunological redundancy. Semin Immunol. (2018) 36:112. doi: 10.1016/j.smim.2017.12.008

9. Jouanguy E, Beziat V, Mogensen TH, Casanova JL, Tangye SG, Zhang SY. Human inborn errors of immunity to herpes viruses. Curr Opin Immunol. (2020) 62:106-22. doi: 10.1016/j.coi.2020.01.004

10. Casanova JL, Abel L. The human genetic determinism of life-threatening infectious diseases: genetic heterogeneity and physiological homogeneity? Hum Genet. (2020) 139:681-94. doi: 10.1007/s00439-020-02184-w

11. Zhang SY, Jouanguy E, Ugolini S, Smahi A, Elain G, Romero P, et al. TLR3 deficiency in patients with herpes simplex encephalitis. Science. (2007) 317:1522-7. doi: 10.1126/science.1139522

12. Zhang SY, Clark NE, Freije CA, Pauwels E, Taggart AJ, Okada S, et al. Inborn errors of RNA lariat metabolism in humans with brainstem viral infection. Cell. (2018) 172:952-65.e18. doi: 10.1016/j.cell.2018.02.019

13. Ogunjimi B, Zhang SY, Sorensen KB, Skipper KA, Carter-Timofte M, Kerner $\mathrm{G}$, et al. Inborn errors in RNA polymerase III underlie severe varicella zoster virus infections. J Clin Invest. (2017) 127:3543-56. doi: 10.1172/JCI92280

14. Carter-Timofte ME, Hansen AF, Christiansen M, Paludan SR, Mogensen TH. Mutations in RNA polymerase III genes and defective DNA sensing in adults with varicella-zoster virus CNS infection. Genes Immun. (2019) 20:214-23. doi: 10.1038/s41435-018-0027-y

15. Carter-Timofte ME, Hansen AF, Mardahl M, Fribourg S, Rapaport F, Zhang S-Y, et al. Varicella-zoster virus CNS vasculitis and RNA polymerase III gene mutation in identical twins. Neurol. Neuroimmunol. Neuroinflamm. (2018) 5:e500. doi: 10.1212/NXI.0000000000000500

16. Ciancanelli MJ, Huang SX, Luthra P, Garner H, Itan Y, Volpi S, et al. Infectious disease. Life-threatening influenza and impaired interferon amplification in human IRF7 deficiency. Science. (2015) 348:448-53. doi: 10.1126/science.aaa1578 finalized the manuscript and all co-authors read, corrected, and approved the final version of the manuscript. TM prepared Figure 1, whereas MC-T prepared Figure 2 with input from co-authors.

\section{FUNDING}

The group has received funding for COVID-19 research by Independent Research Council Denmark (0214-00001B) and Grosserer L. F. Foght's foundation.
17. Hernandez N, Melki I, Jing H, Habib T, Huang SSY, Danielson J, et al. Lifethreatening influenza pneumonitis in a child with inherited IRF9 deficiency. J Exp Med. (2018) 215:2567-85. doi: 10.1084/jem.20180628

18. Lim HK, Huang SXL, Chen J, Kerner G, Gilliaux O, Bastard P, et al. Severe influenza pneumonitis in children with inherited TLR3 deficiency. J Exp Med. (2019) 216:2038-56. doi: 10.1084/jem.20181621

19. Sologuren I, Martinez-Saavedra MT, Sole-Violan J, de Borges de Oliveira E Jr, Betancor E, Casas I, et al. Lethal influenza in two related adults with inherited GATA2 deficiency. J Clin Immunol. (2018) 38:51326. doi: 10.1007/s10875-018-0512-0

20. Jorgensen SE, Christiansen M, Ryo LB, Gad HH, Gjedsted J, Staeheli P, et al. Defective RNA sensing by RIG-I in severe influenza virus infection. Clin Exp Immunol. (2018) 192:366-76. doi: 10.1111/cei.13120

21. Lamborn IT, Jing H, Zhang Y, Drutman SB, Abbott JK, Munir S, et al. Recurrent rhinovirus infections in a child with inherited MDA5 deficiency. $J$ Exp Med. (2017) 214:1949-72. doi: 10.1084/jem.20161759

22. de Jong SJ, Crequer A, Matos I, Hum D, Gunasekharan V, Lorenzo L, et al. The human CIB1-EVER1-EVER2 complex governs keratinocyteintrinsic immunity to beta-papillomaviruses. J Exp Med. (2018) 215:2289310. doi: 10.1084 /jem.20170308

23. Bottino C, Falco M, Parolini S, Marcenaro E, Augugliaro R, Sivori S, et al. NTB-A [correction of GNTB-A], a novel SH2D1A-associated surface molecule contributing to the inability of natural killer cells to kill EpsteinBarr virus-infected B cells in X-linked lymphoproliferative disease. J Exp Med. (2001) 194:235-46. doi: 10.1084/jem.194.3.235

24. Salzer E, Daschkey S, Choo S, Gombert M, Santos-Valente E, Ginzel $\mathrm{S}$, et al. Combined immunodeficiency with life-threatening EBVassociated lymphoproliferative disorder in patients lacking functional CD27. Haematologica. (2013) 98:473-8. doi: 10.3324/haematol.2012.068791

25. Marsh RA, Madden L, Kitchen BJ, Mody R, McClimon B, Jordan $\mathrm{MB}$, et al. XIAP deficiency: a unique primary immunodeficiency best classified as X-linked familial hemophagocytic lymphohistiocytosis and not as X-linked lymphoproliferative disease. Blood. (2010) 116:1079_ 82. doi: 10.1182/blood-2010-01-256099

26. Linka RM, Risse SL, Bienemann K, Werner M, Linka Y, Krux F, et al. Loss-of-function mutations within the IL-2 inducible kinase ITK in patients with EBV-associated lymphoproliferative diseases. Leukemia. (2012) 26:96371. doi: 10.1038/leu.2011.371

27. Li FY, Chaigne-Delalande B, Su H, Uzel G, Matthews H, Lenardo MJ. XMEN disease: a new primary immunodeficiency affecting $\mathrm{Mg} 2+$ regulation of immunity against Epstein-Barr virus. Blood. (2014) 123:214852. doi: 10.1182/blood-2013-11-538686

28. Drutman SB, Mansouri D, Mahdaviani SA, Neehus AL, Hum D, Bryk R, et al. Fatal cytomegalovirus infection in an adult with inherited NOS2 deficiency. N Engl J Med. (2020) 382:437-45. doi: 10.1056/NEJMoa1910640

29. Hambleton S, Goodbourn S, Young DF, Dickinson P, Mohamad SM, Valappil $\mathrm{M}$, et al. STAT2 deficiency and susceptibility to viral illness in humans. Proc Natl Acad Sci USA. (2013) 110:3053-8. doi: 10.1073/pnas.1220098110

30. Duncan CJ, Mohamad SM, Young DF, Skelton AJ, Leahy TR, Munday DC, et al. Human IFNAR2 deficiency: Lessons for antiviral immunity. Sci Transl Med. (2015) 7:307ra154. doi: 10.1126/scitranslmed.aac4227

31. Bajema KL, Oster AM, McGovern OL, Lindstrom S, Stenger MR, Anderson TC, et al. Persons evaluated for 2019. novel Coronavirus - 
United States, January. 2020. MMWR Morb Mortal Wkly Rep. (2020) 69:16670. doi: $10.15585 / \mathrm{mmwr} . \mathrm{mm} 6906 \mathrm{e} 1$

32. Huang C, Wang Y, Li X, Ren L, Zhao J, Hu Y, et al. Clinical features of patients infected with 2019 novel coronavirus in Wuhan, China. Lancet. (2020) 395:497-506. doi: 10.1016/S0140-6736(20)30183-5

33. Yang X, Yu Y, Xu J, Shu H, Xia J, Liu H, et al. Clinical course and outcomes of critically ill patients with SARS-CoV-2 pneumonia in Wuhan, China: a single-centered, retrospective, observational study. Lancet Respir Med. (2020) 8:475-81. doi: 10.1016/S2213-2600(20)30079-5

34. Zhu J, Ji P, Pang J, Zhong Z, Li H, He C, et al. Clinical characteristics of 3,062 COVID-19 patients: a meta-analysis. J Med Virol. (2020). doi: 10.1002/jmv.25884. [Epub ahead of print].

35. Huang L, Zhang X, Zhang X, Wei Z, Zhang L, Xu J, et al. Rapid asymptomatic transmission of COVID-19 during the incubation period demonstrating strong infectivity in a cluster of youngsters aged 16-23 years outside Wuhan and characteristics of young patients with COVID-19: a prospective contacttracing study. J Infect. (2020) 80:e1-13. doi: 10.1016/j.jinf.2020.03.006

36. Wu Z, McGoogan JM. Characteristics of and important lessons from the coronavirus disease 2019. (COVID-19) outbreak in China: summary of a report of 72314 cases from the chinese center for disease control and prevention. JAMA. (2020). doi: 10.1001/jama.2020.2648. [Epub ahead of print].

37. Wang D, Hu B, Hu C, Zhu F, Liu X, Zhang J, et al. Clinical characteristics of 138 hospitalized patients with 2019. novel coronavirus-infected pneumonia in Wuhan, China. JAMA. (2020) 323:1061-9. doi: 10.1001/jama.2020.1585

38. Guan WJ, Ni ZY, Hu Y, Liang WH, Ou CQ, He JX, et al. Clinical characteristics of coronavirus disease 2019 in China. N Engl J Med. (2020) 382:1708-20. doi: 10.1056/NEJMoa2002032

39. Lechien JR, Chiesa-Estomba CM, De Siati DR, Horoi M, Le Bon SD, Rodriguez A, et al. Olfactory and gustatory dysfunctions as a clinical presentation of mild-to-moderate forms of the coronavirus disease (COVID19): a multicenter European study. Eur Arch Otorhinolaryngol. (2020) 6:1-11. doi: 10.1007/s00405-020-05965-1

40. Leonardi M, Padovani A, McArthur JC. Neurological manifestations associated with COVID-19: a review and a call for action. J Neurol. (2020) 267:1573-6. doi: 10.1007/s00415-020-09896-z

41. Roman GC, Spencer PS, Reis J, Buguet A, Faris MEA, Katrak SM, et al. The neurology of COVID-19 revisited: a proposal from the Environmental Neurology Specialty Group of the World Federation of Neurology to implement international neurological registries. I Neurol Sci. (2020) 414:116884. doi: 10.1016/j.jns.2020.116884

42. Cheung KS, Hung IF, Chan PP, Lung KC, Tso E, Liu R, et al. Gastrointestinal manifestations of SARS-CoV-2 infection and virus load in fecal samples from the hong kong cohort and systematic review and meta-analysis. Gastroenterology. (2020). doi: 10.1053/j.gastro.2020.03.065. [Epub ahead of print].

43. Henry BM. COVID-19, ECMO, and lymphopenia: a word of caution. Lancet Respir Med. (2020) 8:e24. doi: 10.1016/S2213-2600(20)30119-3

44. Connors JM, Levy JH. COVID-19 and its implications for thrombosis and anticoagulation. Blood. (2020) 135:2033-40. doi: 10.1182/blood.2020006000

45. Dolhnikoff M, Duarte-Neto AN, de Almeida Monteiro RA, da Silva LFF, de Oliveira EP, Saldiva PHN, et al. Pathological evidence of pulmonary thrombotic phenomena in severe COVID-19. J Thromb Haemost. (2020) 18:1517-9. doi: 10.1111/jth.14844

46. Al-Samkari H, Karp Leaf RS, Dzik WH, Carlson JC, Fogerty AE, Waheed A, et al. COVID and coagulation: bleeding and thrombotic manifestations of SARS-CoV2 Infection. Blood. (2020). doi: 10.1182/blood.2020006520. [Epub ahead of print].

47. Edler C, Schroder AS, Aepfelbacher M, Fitzek A, Heinemann A, Heinrich F, et al. Dying with SARS-CoV-2 infection-an autopsy study of the first consecutive 80 cases in Hamburg, Germany. Int J Legal Med. (2020) 134:1275-84. doi: 10.1007/s00414-020-02317-w

48. Lagunas-Rangel FA, Chavez-Valencia V. High IL-6/IFN-gamma ratio could be associated with severe disease in COVID-19 patients. J Med Virol. (2020). doi: 10.1002/jmv.25900. [Epub ahead of print].

49. Henderson LA, Canna SW, Schulert GS, Volpi S, Lee PY, Kernan KF, et al. On the alert for cytokine storm: immunopathology in COVID-19. Arthritis Rheumatol. (2020). doi: 10.1002/art.41285. [Epub ahead of print].
50. Cao X. COVID-19: immunopathology and its implications for therapy. Nat Rev Immunol. (2020) 20:269-70. doi: 10.1038/s41577-020-0308-3

51. Licciardi F, Giani T, Baldini L, Favalli EG, Caporali R, Cimaz R. COVID-19 and what pediatric rheumatologists should know: a review from a highly affected country. Pediatr Rheumatol Online J. (2020) 18:35. doi: 10.1186/s12969-020-00422-z

52. Ritchie AI, Singanayagam A. Immunosuppression for hyperinflammation in COVID-19: a double-edged sword? Lancet. (2020) 395:1111. doi: 10.1016/S0140-6736(20)30691-7

53. Jones VG, Mills M, Suarez D, Hogan CA, Yeh D, Bradley Segal J, et al. COVID-19 and kawasaki disease: novel virus and novel case. Hosp Pediatr. (2020) 10:537-40. doi: 10.1542/hpeds.2020-0123

54. Riphagen S, Gomez X, Gonzalez-Martinez C, Wilkinson N, Theocharis P. Hyperinflammatory shock in children during COVID-19 pandemic. Lancet. (2020) 395:1607-8. doi: 10.1016/S0140-6736(20)31094-1

55. Woo PC, Huang Y, Lau SK, Yuen KY. Coronavirus genomics and bioinformatics analysis. Viruses. (2010) 2:1804-20. doi: 10.3390/v2081803

56. Woo PC, Lau SK, Lam CS, Lau CC, Tsang AK, Lau JH, et al. Discovery of seven novel Mammalian and avian coronaviruses in the genus deltacoronavirus supports bat coronaviruses as the gene source of alphacoronavirus and betacoronavirus and avian coronaviruses as the gene source of gammacoronavirus and deltacoronavirus. J Virol. (2012) 86:39954008. doi: 10.1128/JVI.06540-11

57. Lu R, Zhao X, Li J, Niu P, Yang B, Wu H, et al. Genomic characterisation and epidemiology of 2019 novel coronavirus: implications for virus origins and receptor binding. Lancet. (2020) 395:565-74. doi: 10.1016/S0140-6736(20)30251-8

58. Zhou P, Yang XL, Wang XG, Hu B, Zhang L, Zhang W, et al. A pneumonia outbreak associated with a new coronavirus of probable bat origin. Nature. (2020) 579:270-3. doi: 10.1038/s41586-020-2012-7

59. Li X, Zai J, Zhao Q, Nie Q, Li Y, Foley BT, et al. Evolutionary history, potential intermediate animal host, and cross-species analyses of SARS-CoV-2. J Med Virol. (2020) 92:602-11. doi: 10.1002/jmv.25731

60. Andersen KG, Rambaut A, Lipkin WI, Holmes EC, Garry RF. The proximal origin of SARS-CoV-2. Nat Med. (2020) 26:450-2. doi: 10.1038/s41591-020-0820-9

61. Wu C, Liu Y, Yang Y, Zhang P, Zhong W, Wang Y, et al. Analysis of therapeutic targets for SARS-CoV-2 and discovery of potential drugs by computational methods. Acta Pharm Sin B. (2020) 92:60211. doi: $10.1016 /$ j.apsb.2020.02.008

62. Li W, Moore MJ, Vasilieva N, Sui J, Wong SK, Berne MA, et al. Angiotensinconverting enzyme 2 is a functional receptor for the SARS coronavirus. Nature. (2003) 426:450-4. doi: 10.1038/nature02145

63. Matsuyama S, Nagata N, Shirato K, Kawase M, Takeda M, Taguchi F. Efficient activation of the severe acute respiratory syndrome coronavirus spike protein by the transmembrane protease TMPRSS2. J Virol. (2010) 84:12658-64. doi: 10.1128/JVI.01542-10

64. Shulla A, Heald-Sargent T, Subramanya G, Zhao J, Perlman S, Gallagher T. A transmembrane serine protease is linked to the severe acute respiratory syndrome coronavirus receptor and activates virus entry. J Virol. (2011) 85:873-82. doi: 10.1128/JVI.02062-10

65. Yang XH, Deng W, Tong Z, Liu YX, Zhang LF, Zhu H, et al. Mice transgenic for human angiotensin-converting enzyme 2 provide a model for SARS coronavirus infection. Comp Med. (2007) 57:450-9.

66. Wrapp D, Wang N, Corbett KS, Goldsmith JA, Hsieh CL, Abiona O, et al. Cryo-EM structure of the 2019-nCoV spike in the prefusion conformation. Science. (2020) 367:1260-3. doi: 10.1126/science.abb2507

67. Hoffmann M, Kleine-Weber H, Schroeder S, Kruger N, Herrler T, Erichsen S, et al. SARS-CoV-2 cell entry depends on ACE2 and TMPRSS2 and is blocked by a clinically proven protease inhibitor. Cell. (2020) 181:27180.e8. doi: 10.1016/j.cell.2020.02.052

68. Lan J, Ge J, Yu J, Shan S, Zhou H, Fan S, et al. Structure of the SARS-CoV-2 spike receptor-binding domain bound to the ACE2 receptor. Nature. (2020) 581:215-20. doi: 10.1038/s41586-020-2180-5

69. Kirchdoerfer RN, Wang N, Pallesen J, Wrapp D, Turner HL, Cottrell $\mathrm{CA}$, et al. Stabilized coronavirus spikes are resistant to conformational changes induced by receptor recognition or proteolysis. Sci Rep. (2018) 8:15701. doi: 10.1038/s41598-018-36918-8 
70. Zhao Y, Zhao Z, Wang Y, Zhou Y, Ma Y, Zuo W. Single-cell RNA expression profiling of ACE2, the putative receptor of Wuhan 2019-nCov. bioRxiv. (2020). doi: 10.1101/2020.01.26.919985. [Epub ahead of print].

71. Hamming I, Timens W, Bulthuis ML, Lely AT, Navis G, van Goor H. Tissue distribution of ACE2 protein, the functional receptor for SARS coronavirus. a first step in understanding SARS pathogenesis. J Pathol. (2004) 203:6317. doi: $10.1002 /$ path.1570

72. Zou X, Chen K, Zou J, Han P, Hao J, Han Z. Single-cell RNA-seq data analysis on the receptor ACE2 expression reveals the potential risk of different human organs vulnerable to 2019-nCoV infection. Front Med. (2020) 14:185-92. doi: 10.1007/s11684-020-0754-0

73. Chen G, Wu D, Guo W, Cao Y, Huang D, Wang H, et al. Clinical and immunologic features in severe and moderate Coronavirus Disease 2019. J Clin Invest. (2020) 130:2620-9. doi: 10.1101/2020.02.16.20023903

74. Prompetchara E, Ketloy C, Palaga T. Immune responses in COVID-19 and potential vaccines: Lessons learned from SARS and MERS epidemic. Asian Pac J Allergy Immunol. (2020) 38:1-9. doi: 10.12932/AP-200220-0772

75. Li Y, Chen M, Cao H, Zhu Y, Zheng J, Zhou H. Extraordinary GUrich single-strand RNA identified from SARS coronavirus contributes an excessive innate immune response. Microbes Infect. (2013) 15:8895. doi: 10.1016/j.micinf.2012.10.008

76. Kawasaki T, Kawai T. Toll-like receptor signaling pathways. Front Immunol. (2014) 5:461. doi: 10.3389/fimmu.2014.00461

77. Totura AL, Whitmore A, Agnihothram S, Schafer A, Katze MG, Heise MT, et al. Toll-like receptor 3 signaling via TRIF contributes to a protective innate immune response to severe acute respiratory syndrome coronavirus infection. mBio. (2015) 6:e00638-15. doi: 10.1128/mBio.00638-15

78. Sheahan T, Morrison TE, Funkhouser W, Uematsu S, Akira S, Baric RS, et al. MyD88 is required for protection from lethal infection with a mouse-adapted SARS-CoV. PLoS Pathog. (2008) 4:e1000240. doi: 10.1371/journal.ppat.1000240

79. Gralinski LE, Menachery VD, Morgan AP, Totura AL, Beall A, Kocher J, et al. Allelic variation in the toll-like receptor adaptor protein Ticam2 contributes to SARS-coronavirus pathogenesis in mice. G3. (2017) 7:165363. doi: $10.1534 / \mathrm{g} 3.117 .041434$

80. Cameron MJ, Ran L, Xu L, Danesh A, Bermejo-Martin JF, Cameron $\mathrm{CM}$, et al. Interferon-mediated immunopathological events are associated with atypical innate and adaptive immune responses in patients with severe acute respiratory syndrome. J Virol. (2007) 81:8692-706. doi: 10.1128/JVI.00527-07

81. Faure E, Poissy J, Goffard A, Fournier C, Kipnis E, Titecat M, et al. Distinct immune response in two MERS-CoV-infected patients: can we go from bench to bedside? PLoS One. (2014) 9:e88716. doi: 10.1371/journal.pone.0088716

82. Ku CL, von Bernuth H, Picard C, Zhang SY, Chang HH, Yang K, et al. Selective predisposition to bacterial infections in IRAK-4-deficient children: IRAK-4-dependent TLRs are otherwise redundant in protective immunity. $J$ Exp Med. (2007) 204:2407-22. doi: 10.1084/jem.20070628

83. Casanova JL, Abel L. Lethal infectious diseases as inborn errors of immunity: toward a synthesis of the germ and genetic theories. Annu Rev Pathol. (2020). doi: 10.1146/annurev-pathol-031920-101429. [Epub ahead of print].

84. Zalinger ZB, Elliott R, Rose KM, Weiss SR. MDA5 Is Critical to Host Defense during Infection with Murine Coronavirus. J Virol. (2015) 89:1233040. doi: 10.1128/JVI.01470-15

85. Menachery VD, Debbink K, Baric RS. Coronavirus non-structural protein 16: evasion, attenuation, and possible treatments. Virus Res. (2014) 194:1919. doi: 10.1016/j.virusres.2014.09.009

86. Menachery VD, Yount BL, Jr., Josset L, Gralinski LE, Scobey T, et al. Attenuation and restoration of severe acute respiratory syndrome coronavirus mutant lacking 2'-o-methyltransferase activity. J Virol. (2014) 88:4251-64. doi: 10.1128/JVI.03571-13

87. Zust R, Cervantes-Barragan L, Habjan M, Maier R, Neuman BW, Ziebuhr $\mathrm{J}$, et al. Ribose 2'-O-methylation provides a molecular signature for the distinction of self and non-self mRNA dependent on the RNA sensor Mda5. Nat Immunol. (2011) 12:137-43. doi: 10.1038/ni.1979

88. Pillai PS, Molony RD, Martinod K, Dong H, Pang IK, Tal MC, et al. Mx1 reveals innate pathways to antiviral resistance and lethal influenza disease. Science. (2016) 352:463-6. doi: 10.1126/science.aaf3926
89. Nieto-Torres JL, Verdia-Baguena C, Jimenez-Guardeno JM, Regla-Nava JA, Castano-Rodriguez C, Fernandez-Delgado R, et al. Severe acute respiratory syndrome coronavirus $\mathrm{E}$ protein transports calcium ions and activates the NLRP3 inflammasome. Virology. (2015) 485:3309. doi: 10.1016/j.virol.2015.08.010

90. Shi CS, Nabar NR, Huang NN, Kehrl JH. SARS-Coronavirus open reading frame- $8 \mathrm{~b}$ triggers intracellular stress pathways and activates NLRP3 inflammasomes. Cell Death Discov. (2019) 5:101. doi: 10.1038/s41420-019-0181-7

91. Chen IY, Moriyama M, Chang MF, Ichinohe T. Severe acute respiratory syndrome coronavirus viroporin 3a activates the NLRP3 inflammasome. Front Microbiol. (2019) 10:50. doi: 10.3389/fmicb.2019.00050

92. Yap JKY, Moriyama M, Iwasaki A. Inflammasomes and pyroptosis as therapeutic targets for COVID-19. J Immunol. (2020). doi: 10.4049/jimmunol.2000513. [Epub ahead of print].

93. Barnes BJ, Adrover JM, Baxter-Stoltzfus A, Borczuk A, CoolsLartigue J, Crawford JM, et al. Targeting potential drivers of COVID-19: Neutrophil extracellular traps. J Exp Med. (2020) 217:e20200652. doi: 10.1084/jem.20200652

94. Zuo Y, Yalavarthi S, Shi H, Gockman K, Zuo M, Madison JA, et al. Neutrophil extracellular traps in COVID-19. JCI Insight. (2020) 5:11. doi: 10.1101/2020.04.30.20086736

95. Dahl H, Linde A, Strannegard O. In vitro inhibition of SARS virus replication by human interferons. Scand J Infect Dis. (2004) 36:82931. doi: 10.1080/00365540410021144

96. Haagmans BL, Kuiken T, Martina BE, Fouchier RA, Rimmelzwaan GF, van Amerongen G, et al. Pegylated interferon-alpha protects type 1 pneumocytes against SARS coronavirus infection in macaques. Nat Med. (2004) 10:2903. doi: $10.1038 / \mathrm{nm} 1001$

97. Sainz B, Jr., Mossel EC, Peters CJ, Garry RF. Interferon-beta and interferongamma synergistically inhibit the replication of severe acute respiratory syndrome-associated coronavirus (SARS-CoV). Virology. (2004) 329:117. doi: 10.1016/j.virol.2004.08.011

98. Stroher U, DiCaro A, Li Y, Strong JE, Aoki F, Plummer F, et al. Severe acute respiratory syndrome-related coronavirus is inhibited by interferon- alpha. $J$ Infect Dis. (2004) 189:1164-7. doi: 10.1086/382597

99. Kumaki Y, Ennis J, Rahbar R, Turner JD, Wandersee MK, Smith AJ, et al. Single-dose intranasal administration with mDEF201 (adenovirus vectored mouse interferon-alpha) confers protection from mortality in a lethal SARS-CoV BALB/c mouse model. Antiviral Res. (2011) 89:7582. doi: 10.1016/j.antiviral.2010.11.007

100. Cinatl J, Morgenstern B, Bauer G, Chandra P, Rabenau H, Doerr HW. Treatment of SARS with human interferons. Lancet. (2003) 362:2934. doi: 10.1016/S0140-6736(03)13973-6

101. Totura AL, Baric RS. SARS coronavirus pathogenesis: host innate immune responses and viral antagonism of interferon. Curr Opin Virol. (2012) 2:26475. doi: 10.1016/j.coviro.2012.04.004

102. Yoshikawa T, Hill TE, Yoshikawa N, Popov VL, Galindo CL, Garner HR, et al. Dynamic innate immune responses of human bronchial epithelial cells to severe acute respiratory syndrome-associated coronavirus infection. PLoS One. (2010) 5:e8729. doi: 10.1371/journal.pone.0008729

103. Blanco-Melo D, Nilsson-Payant BE, Liu WC, Uhl S, Hoagland D, Moller $\mathrm{R}$, et al. Imbalanced host response to SARS-CoV-2 drives development of COVID-19. Cell. (2020) 181:1036-45. e9. doi: 10.1016/j.cell.2020.04.026

104. Chu H, Chan JF, Wang Y, Yuen TT, Chai Y, Hou Y, et al. Comparative replication and immune activation profiles of SARS-CoV-2 and SARS-CoV in human lungs: an ex vivo study with implications for the pathogenesis of COVID-19. Clin Infect Dis. (2020). doi: 10.1093/cid/ciaa410. [Epub ahead of print].

105. Kindler E, Thiel V. To sense or not to sense viral RNA-essentials of coronavirus innate immune evasion. Curr Opin Microbiol. (2014) 20:6975. doi: 10.1016/j.mib.2014.05.005

106. Zinzula L, Tramontano E. Strategies of highly pathogenic RNA viruses to block dsRNA detection by RIG-I-like receptors: hide, mask, hit. Antiviral Res. (2013) 100:615-35. doi: 10.1016/j.antiviral.2013.10.002

107. Kindler E, Thiel V, Weber F. Interaction of SARS and MERS coronaviruses with the antiviral interferon response. Adv Virus Res. (2016) 96:21943. doi: 10.1016/bs.aivir.2016.08.006 
108. Channappanavar R, Zhao J, Perlman S. T cell-mediated immune response to respiratory coronaviruses. Immunol Res. (2014) 59:118-28. doi: 10.1007/s12026-014-8534-Z

109. Li CK, Wu H, Yan H, Ma S, Wang L, Zhang M, et al. T cell responses to whole SARS coronavirus in humans. J Immunol. (2008) 181:5490500. doi: 10.4049/jimmunol.181.8.5490

110. Qin C, Zhou L, Hu Z, Zhang S, Yang S, Tao Y, et al. Dysregulation of immune response in patients with COVID-19 in Wuhan, China. Clin Infect Dis. (2020). doi: 10.1093/cid/ciaa248. [Epub ahead of print].

111. Pedersen SF, Ho YC. SARS-CoV-2: a storm is raging. J Clin Invest. (2020) 130:2202-5. doi: 10.1172/JCI137647

112. Diao B, Wang C, Tan Y, Chen X, Liu Y, Ning L, et al. Reduction and functional exhaustion of $t$ cells in patients with coronavirus disease 2019. (COVID-19). Front Immunol. (2020) 11:827. doi: 10.3389/fimmu.2020.00827

113. Zheng HY, Zhang M, Yang CX, Zhang N, Wang XC, Yang XP, et al. Elevated exhaustion levels and reduced functional diversity of $\mathrm{T}$ cells in peripheral blood may predict severe progression in COVID-19 patients. Cell $\mathrm{Mol}$ Immunol. (2020) 17:541-43. doi: 10.1038/s41423-020-0401-3

114. Grifoni A, Weiskopf D, Ramirez SI, Mateus J, Dan JM, Moderbacher $\mathrm{CR}$, et al. Targets of $\mathrm{T}$ cell responses to SARS-CoV-2 coronavirus in humans with COVID-19 disease and unexposed individuals. Cell. (2020). doi: 10.1016/j.cell.2020.05.015. [Epub ahead of print].

115. Channappanavar R, Fett C, Zhao J, Meyerholz DK, Perlman S. Virusspecific memory CD8 T cells provide substantial protection from lethal severe acute respiratory syndrome coronavirus infection. J Virol. (2014) 88:11034-44. doi: 10.1128/JVI.01505-14

116. Xu Z, Shi L, Wang Y, Zhang J, Huang L, Zhang C, et al. Pathological findings of COVID-19 associated with acute respiratory distress syndrome. Lancet Respir Med. (2020) 8:420-2. doi: 10.1016/S2213-2600(20)30076-X

117. Liao M, Liu Y, Yuan J, Wen Y, Xu G, Zhao J, et al. Single-cell landscape of bronchoalveolar immune cells in patients with COVID-19. Nat Med. (2020) 26:842-44. doi: 10.1038/s41591-020-0901-9

118. Channappanavar R, Fehr AR, Vijay R, Mack M, Zhao J, Meyerholz DK, et al. Dysregulated type i interferon and inflammatory monocyte-macrophage responses cause lethal pneumonia in SARS-CoV-infected Mice. Cell Host Microbe. (2016) 19:181-93. doi: 10.1016/j.chom.2016.01.007

119. Wolfel R, Corman VM, Guggemos W, Seilmaier M, Zange S, Muller MA, et al. Virological assessment of hospitalized patients with COVID-2019. Nature. (2020) 581:465-69. doi: 10.1038/s41586-020-2196-x

120. Hsueh PR, Huang LM, Chen PJ, Kao CL, Yang PC. Chronological evolution of IgM, IgA, IgG and neutralisation antibodies after infection with SARS-associated coronavirus. Clin Microbiol Infect. (2004) 10:10626. doi: 10.1111/j.1469-0691.2004.01009.x

121. Zhu M. SARS Immunity and Vaccination. Cell Mol Immunol. (2004) 1:193-8.

122. $\mathrm{Li} \mathrm{G}$, Chen $\mathrm{X}, \mathrm{Xu} \mathrm{A}$. Profile of specific antibodies to the SARS-associated coronavirus. N Engl J Med. (2003) 349:5089. doi: 10.1056/NEJM200307313490520

123. Kellam P, Barclay W. The dynamics of humoral immune responses following SARS-CoV-2 infection and the potential for reinfection. J Gen Virol. (2020). doi: 10.1099/jgv.0.001439. [Epub ahead of print].

124. Long QX, Liu BZ, Deng HJ, Wu GC, Deng K, Chen YK, et al. Antibody responses to SARS-CoV-2 in patients with COVID-19. Nat Med. (2020) 26:845-8. doi: 10.1038/s41591-020-0897-1

125. Zhao J, Yuan Q, Wang H, Liu W, Liao X, Su Y, et al. Antibody responses to SARS-CoV-2 in patients of novel coronavirus disease 2019. Clin Infect Dis. (2020). doi: 10.1093/cid/ciaa344. [Epub ahead of print].

126. To KK, Tsang OT, Leung WS, Tam AR, Wu TC, Lung DC, et al. Temporal profiles of viral load in posterior oropharyngeal saliva samples and serum antibody responses during infection by SARS-CoV2: an observational cohort study. Lancet Infect Dis. (2020) 20:565-74. doi: 10.1016/S1473-3099(20)30196-1

127. Liu W, Fontanet A, Zhang PH, Zhan L, Xin ZT, Baril L, et al. Twoyear prospective study of the humoral immune response of patients with severe acute respiratory syndrome. J Infect Dis. (2006) 193:7925. doi: 10.1086/500469

128. Wu LP, Wang NC, Chang YH, Tian XY, Na DY, Zhang LY, et al. Duration of antibody responses after severe acute respiratory syndrome. Emerg Infect Dis. (2007) 13:1562-4. doi: 10.3201/eid1310.070576
129. Ng OW, Chia A, Tan AT, Jadi RS, Leong HN, Bertoletti A, et al. Memory $\mathrm{T}$ cell responses targeting the SARS coronavirus persist up to 11 years post-infection. Vaccine. (2016) 34:2008-14. doi: 10.1016/j.vaccine.2016. 02.063

130. Longdon B, Brockhurst MA, Russell CA, Welch JJ, Jiggins FM. The evolution and genetics of virus host shifts. PLoS Pathog. (2014) 10:e1004395. doi: 10.1371/journal.ppat.1004395

131. Bucciol G, Moens L, Bosch B, Bossuyt X, Casanova JL, Puel A, et al. Lessons learned from the study of human inborn errors of innate immunity. J Allergy Clin Immunol. (2019) 143:507-27. doi: 10.1016/j.jaci.2018. 07.013

132. Ziegler T, Matikainen S, Ronkko E, Osterlund $P$, Sillanpaa M, Siren J, et al. Severe acute respiratory syndrome coronavirus fails to activate cytokine-mediated innate immune responses in cultured human monocyte-derived dendritic cells. J Virol. (2005) 79:13800-5. doi: 10.1128/JVI.79.21.13800-13805.2005

133. Law HK, Cheung CY, Ng HY, Sia SF, Chan YO, Luk W, et al. Chemokine up-regulation in SARS-coronavirus-infected, monocyte-derived human dendritic cells. Blood. (2005) 106:2366-74. doi: 10.1182/blood-2004-10-4166

134. Hamano E, Hijikata M, Itoyama S, Quy T, Phi NC, Long HT, et al. Polymorphisms of interferon-inducible genes OAS-1 and MxA associated with SARS in the Vietnamese population. Biochem Biophys Res Commun. (2005) 329:1234-9. doi: 10.1016/j.bbrc.2005.02.101

135. He J, Feng D, de Vlas SJ, Wang H, Fontanet A, Zhang $\mathrm{P}$, et al. Association of SARS susceptibility with single nucleic acid polymorphisms of OAS1 and MxA genes: a case-control study. BMC Infect Dis. (2006) 6:106. doi: 10.1186/1471-2334-6-106

136. Song WC, FitzGerald GA. COVID-19, microangiopathy, hemostatic activation, and complement. J Clin Invest. (2020). doi: 10.1172/JCI140183. [Epub ahead of print].

137. Bosmann M. Complement activation during critical illness: current findings and an outlook in the era of COVID-19. Am J Respir Crit Care Med. (2020). doi: 10.1164/rccm.202005-1926ED. [Epub ahead of print].

138. Kulasekararaj AG, Lazana I, Large J, Posadas K, Eagleton H, Villajin JL, et al. Terminal complement inhibition dampens the inflammation during COVID-19. Br J Haematol. (2020). doi: 10.1111/bjh.16916. [Epub ahead of print].

139. Ezekowitz RA. Role of the mannose-binding lectin in innate immunity. $J$ Infect Dis. (2003) 187(Suppl. 2):S335-9. doi: 10.1086/374746

140. Koch A, Melbye M, Sorensen P, Homoe P, Madsen HO, Molbak K, et al. Acute respiratory tract infections and mannose-binding lectin insufficiency during early childhood. JAMA. (2001) 285:1316-21. doi: 10.1001/jama.285.10.1316

141. Hibberd ML, Sumiya M, Summerfield JA, Booy R, Levin M. Association of variants of the gene for mannose-binding lectin with susceptibility to meningococcal disease. Meningococcal Research Group. Lancet. (1999) 353:1049-53. doi: 10.1016/S0140-6736(98)08350-0

142. Garred P, Madsen HO, Balslev U, Hofmann B, Pedersen C, Gerstoft J, et al. Susceptibility to HIV infection and progression of AIDS in relation to variant alleles of mannose-binding lectin. Lancet. (1997) 349:23640. doi: 10.1016/S0140-6736(96)08440-1

143. Ip WK, Chan KH, Law HK, Tso GH, Kong EK, Wong WH, et al. Mannosebinding lectin in severe acute respiratory syndrome coronavirus infection. $J$ Infect Dis. (2005) 191:1697-704. doi: 10.1086/429631

144. Quinti I, Lougaris V, Milito C, Cinetto F, Pecoraro A, Mezzaroma I, et al. A possible role for B cells in COVID-19? lesson from patients with agammaglobulinemia. J Allergy Clin Immunol. (2020). doi: 10.1016/j.jaci.2020.04.013. [Epub ahead of print].

145. Peiris JS, Chu CM, Cheng VC, Chan KS, Hung IF, Poon LL, et al. Clinical progression and viral load in a community outbreak of coronavirusassociated SARS pneumonia: a prospective study. Lancet. (2003) 361:176772. doi: 10.1016/S0140-6736(03)13412-5

146. Arabi YM, Arifi AA, Balkhy HH, Najm H, Aldawood AS, Ghabashi A, et al. Clinical course and outcomes of critically ill patients with Middle East respiratory syndrome coronavirus infection. Ann Intern Med. (2014) 160:389-97. doi: 10.7326/M13-2486

147. Dauby N. Potential impact of COVID-19 in people living with HIV: experience from previous 21 st century coronaviruses epidemics. AIDS. (2020) 34:1255-6. doi: 10.1097/QAD.0000000000002555 
148. Casanova JL, Su HC, Effort CHG. A global effort to define the human genetics of protective immunity to SARS-CoV-2 infection. Cell. (2020) 181:1194-9. doi: 10.1016/j.cell.2020.05.016

149. Matzaraki V, Kumar V, Wijmenga C, Zhernakova A. The MHC locus and genetic susceptibility to autoimmune and infectious diseases. Genome Biol. (2017) 18:76. doi: 10.1186/s13059-017-1207-1

150. Dimarco AD. Covid-19 and ethnicity: it's too early to point to healthcare provider attitudes as a cause of poorer outcomes. BMJ. (2020) 369:m2181. doi: 10.1136/bmj.m2181

151. Lassale C, Gaye B, Hamer M, Gale CR, David Batty G. Ethnic disparities in hospitalisation for COVID-19 in England: the role of socioeconomic factors, mental health, and inflammatory and pro-inflammatory factors in a community-based cohort study. Brain Behav Immun. (2020). doi: 10.1016/j.bbi.2020.05.074. [Epub ahead of print].

152. Galloway JB, Norton S, Barker RD, Brookes A, Carey I, Clarke BD, et al. A clinical risk score to identify patients with COVID-19 at high risk of critical care admission or death: an observational cohort study. J Infect. (2020). doi: 10.1016/j.jinf.2020.05.064. [Epub ahead of print].

153. Bandi S, Nevid MZ, Mahdavinia M. African American children are at higher risk for COVID-19 infection. Pediatr Allergy Immunol. (2020). doi: 10.1111/pai.13298. [Epub ahead of print].

154. Price-Haywood EG, Burton J, Fort D, Seoane L. Hospitalization and mortality among black patients and white patients with Covid-19. N Engl J Med. (2020). doi: 10.1056/NEJMsa2011686. [Epub ahead of print].

155. Lin M, Tseng HK, Trejaut JA, Lee HL, Loo JH, Chu CC, et al. Association of HLA class I with severe acute respiratory syndrome coronavirus infection. BMC Med Genet. (2003) 4:9. doi: 10.1186/1471-2350-4-9

156. Lau YL, Peiris JS. Pathogenesis of severe acute respiratory syndrome. Curr Opin Immunol. (2005) 17:404-10. doi: 10.1016/j.coi.2005.05.009

157. Ng MH, Lau KM, Li L, Cheng SH, Chan WY, Hui PK, et al. Association of human-leukocyte-antigen class I (B*0703) and class II (DRB1*0301) genotypes with susceptibility and resistance to the development of severe acute respiratory syndrome. J Infect Dis. (2004) 190:515-8. doi: 10.1086/421523

158. Shi Y, Wang Y, Shao C, Huang J, Gan J, Huang X, et al. COVID-19 infection: the perspectives on immune responses. Cell Death Differ. (2020) 27:1451-4. doi: 10.1038/s41418-020-0530-3

159. Zhao J, Yang Y, Huang H, Li D, Gu D, Lu X, et al. Relationship between the ABO Blood Group and the COVID-19 susceptibility. medRxiv. (2020). doi: 10.1101/2020.03.11.20031096. [Epub ahead of print].

160. Cheng Y, Cheng G, Chui CH, Lau FY, Chan PK, Ng MH, et al. ABO blood group and susceptibility to severe acute respiratory syndrome. JAMA. (2005) 293:1450-1. doi: 10.1001/jama.293.12.1450-c

161. Balagopal A, Thomas DL, Thio CL. IL28B and the control of hepatitis C virus infection. Gastroenterology. (2010) 139:186576. doi: 10.1053/j.gastro.2010.10.004

162. Williams FMK, Freidin MB, Mangino M, Couvreur S, Visconti A, Bowyer RCE, et al. Self-reported symptoms of covid-19 including symptoms most predictive of SARS-CoV- 2 infection, are heritable. medRxiv. (2020). doi: 10.1101/2020.04.22.20072124. [Epub ahead of print].

163. Manthiram K, Zhou Q, Aksentijevich I, Kastner DL. The monogenic autoinflammatory diseases define new pathways in human innate immunity and inflammation. Nat Immunol. (2017) 18:832-42. doi: 10.1038/ni.3777

164. Zhang K, Jordan MB, Marsh RA, Johnson JA, Kissell D, Meller J, et al. Hypomorphic mutations in PRF1, MUNC13-4, and STXBP2 are associated with adult-onset familial HLH. Blood. (2011) 118:57948. doi: 10.1182/blood-2011-07-370148

165. Heeg M, Ammann S, Klemann C, Panning M, Falcone V, Hengel H, et al. Is an infectious trigger always required for primary hemophagocytic lymphohistiocytosis? lessons from in utero and neonatal disease. Pediatr Blood Cancer. (2018) 65:e27344. doi: 10.1002/pbc.27344

166. Huang Y, Paxton WA, Wolinsky SM, Neumann AU, Zhang L, He T, et al. The role of a mutant CCR5 allele in HIV-1 transmission and disease progression. Nat Med. (1996) 2:1240-3. doi: 10.1038/nm1196-1240

167. Stawiski EW, Diwanji D, Suryamohan K, Gupta R, Fellouse FA, Sathirapongsasuti JF, et al. Human ACE2 receptor polymorphisms predict SARS-CoV-2 susceptibility. bioRxiv. (2020). doi: 10.1101/2020.04.07.024752. [Epub ahead of print].
168. Asselta R, Paraboschi EM, Mantovani A, Duga S. ACE2 and TMPRSS2 variants and expression as candidates to sex and country differences in COVID-19 severity in Italy. Aging. (2020). doi: 10.18632/aging.103415. [Epub ahead of print].

169. (FDA) USFDA. Corona Virus Disease 2019. (COVID-19) (2020). Available online at: https://www.fda.gov/emergency-preparedness-and-response/ counterterrorism-and-emerging-threats/coronavirus-disease-2019-covid19 (accessed April 10, 2020).

170. EMA. Coronavirus Disease (COVID-19). (2020). Available online at: https:// www.ema.europa.eu/en/human-regulatory/overview/public-health-threats/ coronavirus- disease-covid-19 (accessed April 10, 2020).

171. WHO. "Solidarity" Clinical Trial for COVID-19 Treatments. (2020). Available online at: https://www.who.int/emergencies/diseases/novel-coronavirus2019/global-research-on- novel-coronavirus-2019-ncov/solidarity-clinicaltrial-for-covid-19-treatments (accessed April 5, 2020).

172. Li H, Zhou Y, Zhang M, Wang H, Zhao Q, Liu J. Updated approaches against SARS-CoV-2. Antimicrob Agents Chemother. (2020) 64:e0048320. doi: 10.1128/AAC.00483-20

173. Martinez MA. Compounds with therapeutic potential against novel respiratory 2019 coronavirus. Antimicrob Agents Chemother. (2020) 64:e00399-20. doi: 10.1128/AAC.00399-20

174. Gordon CJ, Tchesnokov EP, Feng JY, Porter DP, Gotte M. The antiviral compound remdesivir potently inhibits RNA-dependent RNA polymerase from Middle East respiratory syndrome coronavirus. J Biol Chem. (2020) 295: 4773-9. doi: 10.1074/jbc.AC120.013056

175. Wang $\mathrm{M}$, Cao $\mathrm{R}$, Zhang $\mathrm{L}$, Yang $\mathrm{X}$, Liu J, $\mathrm{Xu} \mathrm{M}$, et al. Remdesivir and chloroquine effectively inhibit the recently emerged novel coronavirus (2019-nCoV) in vitro. Cell Res. (2020) 30:269-71. doi: 10.1038/s41422-020-0282-0

176. Sheahan TP, Sims AC, Graham RL, Menachery VD, Gralinski LE, Case JB, et al. Broad-spectrum antiviral GS-5734 inhibits both epidemic and zoonotic coronaviruses. Sci Transl Med. (2017) 9:eaal3653. doi: 10.1126/scitranslmed.aal3653

177. Lo MK, Jordan R, Arvey A, Sudhamsu J, Shrivastava-Ranjan P, Hotard AL, et al. GS-5734 and its parent nucleoside analog inhibit Filo-, Pneumo-, and Paramyxoviruses. Sci Rep. (2017) 7:43395. doi: 10.1038/srep43395

178. Sheahan TP, Sims AC, Leist SR, Schäfer A, Won J, Brown AJ, et al. Comparative therapeutic efficacy of remdesivir and combination lopinavir, ritonavir, and interferon beta against MERS-CoV. Nat Commun. (2020) 11:222. doi: 10.1038/s41467-019-13940-6

179. de Wit E, Feldmann F, Cronin J, Jordan R, Okumura A, Thomas T, et al. Prophylactic and therapeutic remdesivir (GS-5734) treatment in the rhesus macaque model of MERS-CoV infection. Proc Natl Acad Sci USA. (2020) 117:6771-6. doi: 10.1073/pnas.1922083117

180. Wang Y, Zhang D, Du G, Du R, Zhao J, Jin Y, et al. Remdesivir in adults with severe COVID-19: a randomised, double-blind, placebo-controlled, multicentre trial. Lancet. (2020) 395:1569-78. doi: 10.1016/S0140-6736(20)31022-9

181. Beigel JH, Tomashek KM, Dodd LE, Mehta AK, Zingman BS, Kalil AC, et al. Remdesivir for the treatment of Covid-19 - preliminary report. N Engl J Med. (2020). doi: 10.1056/NEJMoa2007764. [Epub ahead of print].

182. Goldman JD, Lye DCB, Hui DS, Marks KM, Bruno R, Montejano R, et al. Remdesivir for 5 or 10 days in patients with severe Covid-19. N Engl J Med. (2020). doi: 10.1056/NEJMoa2015301

183. Antinori S, Cossu MV, Ridolfo AL, Rech R, Bonazzetti C, Pagani G, et al. Compassionate remdesivir treatment of severe Covid-19 pneumonia in intensive care unit (ICU) and Non-ICU patients: Clinical outcome and differences in post-treatment hospitalisation status. Pharmacol Res. (2020) 158:104899. doi: 10.1016/j.phrs.2020.104899

184. Zumla A, Chan JF, Azhar EI, Hui DS, Yuen KY. Coronaviruses - drug discovery and therapeutic options. Nat Rev Drug Discov. (2016) 15:32747. doi: 10.1038/nrd.2015.37

185. Choy KT, Yin-Lam Wong A, Kaewpreedee P, Sia SF, Chen D, Yan Hui KP, et al. Remdesivir, lopinavir, emetine, and homoharringtonine inhibit SARS-CoV-2 replication in vitro. Antiviral Res. (2020) 2020:104786. doi: 10.1016/j.antiviral.2020.104786

186. Yao X, Ye F, Zhang M, Cui C, Huang B, Niu P, et al. In vitro antiviral activity and projection of optimized dosing design of hydroxychloroquine for the 
treatment of severe acute respiratory syndrome Coronavirus 2 (SARS-CoV2). Clin Infect Dis. (2020). doi: 10.1093/cid/ciaa237. [Epub ahead of print].

187. Liu J, Cao R, Xu M, Wang X, Zhang H, Hu H, et al. Hydroxychloroquine, a less toxic derivative of chloroquine, is effective in inhibiting SARS-CoV2 infection in vitro. Cell Discov. (2020) 6:16. doi: 10.1038/s41421-0200156-0

188. Cao B, Wang Y, Wen D, Liu W, Wang J, Fan G, et al. A trial of lopinavirritonavir in adults hospitalized with severe Covid-19. N Engl J Med. (2020) 382:1787-99. doi: 10.1056/NEJMc2008043

189. Borba MGS, Val FFA, Sampaio VS, Alexandre MAA, Melo GC, Brito M, et al. Effect of high vs low doses of chloroquine diphosphate as adjunctive therapy for patients hospitalized with severe acute respiratory syndrome coronavirus 2 (SARS-CoV-2) infection: a randomized clinical trial. JAMA Netw Open. (2020) 3:e208857. doi: 10.1001/jamanetworkopen.2020.8857

190. Mahevas M, Tran VT, Roumier M, Chabrol A, Paule R, Guillaud C, et al. Clinical efficacy of hydroxychloroquine in patients with covid-19 pneumonia who require oxygen: observational comparative study using routine care data. BMJ. (2020) 369:m1844. doi: 10.1136/bmj.m1844

191. Boulware DR, Pullen MF, Bangdiwala AS, Pastick KA, Lofgren SM, Okafor EC, et al. A randomized trial of hydroxychloroquine as postexposure prophylaxis for Covid-19. N Engl J Med. (2020). doi: 10.1056/NEJMoa2016638. [Epub ahead of print].

192. Geleris J, Sun Y, Platt J, Zucker J, Baldwin M, Hripcsak G, et al. Observational study of hydroxychloroquine in hospitalized patients with Covid-19. N Engl J Med. (2020) 382:2411-8. doi: 10.1056/NEJMoa2012410

193. Rosenberg ES, Dufort EM, Udo T, Wilberschied LA, Kumar J, Tesoriero J, et al. Association of treatment with hydroxychloroquine or azithromycin with in-hospital mortality in patients with COVID-19 in New York State. JAMA. (2020). doi: 10.1001/jama.2020.8630. [Epub ahead of print].

194. Gautret P, Lagier JC, Parola P, Hoang VT, Meddeb L, Mailhe M, et al. Hydroxychloroquine and azithromycin as a treatment of COVID-19: results of an open-label non-randomized clinical trial. Int J Antimicrob Agents. (2020) 2020:105949. doi: 10.1016/j.ijantimicag.2020.105949

195. Huang M, Tang T, Pang P, Li M, Ma R, Lu J, et al. Treating COVID-19 with chloroquine. J Mol Cell Biol. (2020) 12:322-5. doi: 10.1093/jmcb/mj aa014

196. Mehra MR, Desai SS, Ruschitzka F, Patel AN. Hydroxychloroquine or chloroquine with or without a macrolide for treatment of COVID-19: a multinational registry analysis. Lancet. (2020). doi: 10.1016/S0140-6736(20)31180-6

197. WHO. WHO Director-General's Opening Remarks at the Media Briefing on COVID-19. (2020). Available online at: https://www.who.int/dg/speeches/ detail/who-director-general-s-opening-remarks-at-the-media-briefingon-covid-19-\$-\$25-may-2020 (accessed May 25, 2020).

198. WHO. WHO Director-General's Opening Remarks at the Media Briefing on COVID-19. (2020). Available online at: https://www.who.int/dg/speeches/ detail/who-director-general-s-opening-remarks-at-the-media-briefingon-covid-19-\$-\$03-june-2020 (accessed June 3, 2020).

199. Zhou Y, Vedantham P, Lu K, Agudelo J, Carrion R, Jr., et al. Protease inhibitors targeting coronavirus and filovirus entry. Antiviral Res. (2015) 116:76-84. doi: 10.1016/j.antiviral.2015.01.011

200. FOIPAN. Camostat Mesilate Tablets Information Sheet. Osaka: Ono Pharmaceutical CO., Ltd.

201. Ramsey ML, Nuttall J, Hart PA. A phase $1 / 2$ trial to evaluate the pharmacokinetics, safety, and efficacy of NI-03 in patients with chronic pancreatitis: study protocol for a randomized controlled trial on the assessment of camostat treatment in chronic pancreatitis (TACTIC). Trials. (2019) 20:501. doi: 10.1186/s13063-019-3606-y

202. Clinicaltrials.gov. The Impact of Camostat Mesilate on COVID-19 Infection (CamoCO-19). NCT04321096: Clinicaltrials.gov; (2020). Available online at: https://clinicaltrials.gov/ct2/show/NCT04321096?term=Camostat $\$+$ $\$$ mesylate\&draw=2\&rank=1 (accessed April 16, 2020).

203. Toniati P, Piva S, Cattalini M, Garrafa E, Regola F, Castelli F, et al. Tocilizumab for the treatment of severe COVID-19 pneumonia with hyperinflammatory syndrome and acute respiratory failure: A single center study of 100 patients in Brescia, Italy. Autoimmun Rev. (2020) 19:102568. doi: 10.1016/j.autrev.2020.102568pagebreak

204. Xu X, Han M, Li T, Sun W, Wang D, Fu B, et al. Effective treatment of severe COVID-19 patients with tocilizumab. Proc Natl Acad Sci USA. (2020) 117:10970-5. doi: 10.1073/pnas.2005615117

205. Cavalli G, De Luca G, Campochiaro C, Della-Torre E, Ripa M, Canetti D, et al. Interleukin-1 blockade with high-dose anakinra in patients with COVID-19, acute respiratory distress syndrome, and hyperinflammation: a retrospective cohort study. Lancet Rheumatol. (2020) 2:e325-31. doi: 10.1016/S2665-9913(20)30127-2

206. Huet T, Beaussier H, Voisin O, Jouveshomme S, Dauriat G, Lazareth I, et al. Anakinra for severe forms of COVID-19: a cohort study. Lancet. (2020) 2:e393-400. doi: 10.1016/S2665-9913(20)30164-8

207. Dimopoulos G, de Mast Q, Markou N, Theodorakopoulou M, Komnos A, Mouktaroudi M, et al. Favorable anakinra responses in severe Covid19 patients with secondary hemophagocytic lymphohistiocytosis. Cell Host Microbe. (2020). doi: 10.1016/j.chom.2020.05.007. [Epub ahead of print].

208. Rilinger J, Kern WV, Duerschmied D, Supady A, Bode C, Staudacher $\mathrm{DL}$, et al. A prospective, randomised, double blind placebo-controlled trial to evaluate the efficacy and safety of tocilizumab in patients with severe COVID-19 pneumonia (TOC-COVID): A structured summary of a study protocol for a randomised controlled trial. Trials. (2020) 21:470. doi: 10.1186/s13063-020-04447-3

209. Maes B, Bosteels C, De Leeuw E, Declercq J, Van Damme K, Delporte A, et al. Treatment of severely ill COVID-19 patients with anti-interleukin drugs (COV-AID): A structured summary of a study protocol for a randomised controlled trial. Trials. (2020) 21:468. doi: 10.1186/s13063-020-04453-5

210. Salvarani C, Bajocchi G, Mancuso P, Galli E, Muratore F, Boiardi L, et al. Susceptibility and severity of COVID-19 in patients treated with bDMARDS and tsDMARDs: a population-based study. Ann Rheum Dis. (2020) 79:986-8. doi: 10.1136/annrheumdis-2020-217903

211. Cugno M, Meroni PL, Gualtierotti R, Griffini S, Grovetti E, Torri A, et al. Complement activation in patients with COVID-19: A novel therapeutic target. J Allergy Clin Immunol. (2020). doi: 10.1016/j.jaci.2020.05.006. [Epub ahead of print].

212. WHO. Blueprint, Landscape analysis of therapeutics as 21st March 2020 (2020). Available online at: https://www.who.int/blueprint/prioritydiseases/key-action/Table_of_therapeutics_Appendix_17022020.pdf?ua=1) (accessed April 11, 2020).

213. WHO. DRAFT landscape of COVID-19 candidate vaccines. (2020). Available online at: https:/www.who.int/blueprint/priority-diseases/key-action/ Novel_Coronavirus_Landscape_nCoV_11April2020.PDF?ua=1 (accessed April 12, 2020).

Conflict of Interest: The authors declare that the research was conducted in the absence of any commercial or financial relationships that could be construed as a potential conflict of interest.

Copyright (C) 2020 Carter-Timofte, Jørgensen, Freytag, Thomsen, Brinck Andersen, Al-Mousawi, Hait and Mogensen. This is an open-access article distributed under the terms of the Creative Commons Attribution License (CC BY). The use, distribution or reproduction in other forums is permitted, provided the original author(s) and the copyright owner(s) are credited and that the original publication in this journal is cited, in accordance with accepted academic practice. No use, distribution or reproduction is permitted which does not comply with these terms. 